\section{World Heritage}

Distribution limited

\section{BUR}

WHC-02/CONF.201/15

Paris, 27 May 2002

Original : English/French

\author{
UNITED NATIONS EDUCATIONAL, SCIENTIFIC AND CULTURAL \\ ORGANIZATION \\ CONVENTION CONCERNING THE PROTECTION OF THE WORLD \\ CULTURAL AND NATURAL HERITAGE
}

BUREAU OF THE WORLD HERITAGE COMMITTEE

Twenty-sixth session

Paris, UNESCO Headquarters, Room IV

8 - 13 April 2002

\title{
REPORT OF THE RAPPORTEUR
}




\section{TABLE OF CONTENTS}

I. OPENING SESSION 1

II. AdOPTION OF THE AGENDA AND THE TIMETABLE 2

III. NOMINATIONS TO BE EXAMINED BY THE WORLD HERITAGE COMMITTEE IN $2003 \quad 2$

IV. POLICY/LEGAL ISSUES CONCERNING INSCRIPTION OF PROPERTIES ON THE LIST OF WORLD HERITAGE IN DANGER AND THE POTENTIAL DELETION OF PROPERTIES FROM THE WORLD HERITAGE LIST

V. ORAL REPORT ON THE PROGRESS FOR THE REVISION OF THE OPERATIONAL GUIDELINES

VI. WORLD HERITAGE VISUAL IDENTITY AND LEGAL PROTECTION OF THE EMBLEM

VII. PROGRESS REPORT ON THE ANALYSES OF THE WORLD HERITAGE LIST AND TENTATIVE LISTS AND THE IDENTIFICATION OF UNDERREPRESENTED CATEGORIES OF NATURAL AND CULTURAL HERITAGE

VIII. DISCUSSION ON THE RELATIONSHIP BETWEEN THE WORLD HERITAGE COMMITTEE AND UNESCO

IX. PROGRESS REPORT ON THE PREPARATION OF THE PROPOSED STRATEGIC ORIENTATIONS OF THE WORLD HERITAGE COMMITTEE AND REVISED STRUCTURE OF THE BUDGET OF THE WORLD HERITAGE FUND

X. PROGRESS REPORT ON THE PREPARATION OF THE BUdAPEST DECLARATION ON WORLD HERITAGE

XI. PROGRESS REPORT ON THE ORGANISATION OF EVENTS TO CELEBRATE THE 30TH ANNIVERSARY OF THE WORLD HERITAGE CONVENTION IN 2002

XII. REPORTS ON STATE OF CONSERVATION OF PROPERTIES INSCRIBED ON THE WORLD HERITAGE LIST

XIII. INFORMATION ON TENTATIVE LISTS AND EXAMINATION OF NOMINATIONS OF CULTURAL AND NATURAL PROPERTIES TO THE LIST OF WORLD HERITAGE IN DANGER AND THE WORLD HERITAGE LIST

XIV. REQUESTS FOR INTERNATIONAL ASSISTANCE

XV. PROVISIONAL AGENDA AND TIMETABLE OF THE TWENTY-SIXTH SESSION OF THE WORLD HERITAGE COMMITTEE (BUDAPEST, HUNGARY, 24-29 JUNE 2002)

XVI. OTHER BUSINESS

$\begin{array}{lll}\text { XVII. ADOPTION OF THE REPORT OF THE SESSION } & 38\end{array}$

$\begin{array}{lll}\text { XVIII. ClOSURE OF THE SESSION } & 38\end{array}$ 
A N N E X E S

I. LIST OF PARTICIPANTS

II. PROVISIONAL AGENDA AND TIMETABLE OF THE TWENTY-SIXTH SESSION OF THE WORLD Heritage COMMITTEE (BUDAPEST, HunGary, 24-29 JunE 2002)

III. Statement by the Permanent Delegation of Egypt to Unesco 


\section{I.}

\section{OPENING SESSION}

I.1 The 26th session of the Bureau of the World Heritage Committee was held at UNESCO Headquarters, Paris, from 8 to 13 April 2002. It was attended by the seven members of the Bureau: Egypt, Finland, Greece, Hungary, Mexico, Thailand and South Africa, under the chairmanship of Mr Henrik Lilius (Finland).

I.2 The following States Parties to the Convention were represented as observers: Algeria, Argentina, Australia, Austria, Belgium, Benin, Canada, Chile, China, Colombia, Costa Rica, Czech Republic, El Salvador, France, Gabon, Germany, Guatemala, Holy See, India, Iran (Islamic Republic of), Israel, Italy, Japan, Lithuania, Malaysia, Malawi, Nepal, Netherlands, Nicaragua, Nigeria, Oman, Pakistan, Peru, Philippines, Portugal, Republic of Korea, Russian Federation, Saint Lucia, Saudi Arabia, Slovakia, Slovenia, Spain, Sri Lanka, Switzerland, Tunisia, Turkey, United Arab Emirates, United States of America, United Kingdom, Ukraine, United Republic of Tanzania, Venezuela and Zimbabwe. The Permanent Observer Mission of Palestine to UNESCO, not a State Party to the World Heritage Convention, also participated at the session as an observer.

I.3 Representatives of the Advisory Bodies to the Committee, the International Centre for the Study of the Preservation and Restoration of Cultural Property (ICCROM), the International Council on Monuments and Sites (ICOMOS) and the World Conservation Union (IUCN) attended the session in an advisory capacity. The meeting was also attended by representatives of the following international governmental organizations (IGOs) and non-governmental organizations (NGOs): United Nations Environment Programme (UNEP), United Nations Foundation, and the Nordic World Heritage Office. The List of Participants is included as Annex I.

I.4 The 26th session of the Bureau was opened on behalf of the Director-General of UNESCO, by Mr Mounir Bouchenaki, the Assistant Director-General for Culture. He welcomed the members of the Bureau and the Observers to the session. He noted that the Bureau session was the first World Heritage meeting to be organized under the new calendar adopted as one of a number of reforms adopted by the Committee at its 24th session (Cairns, December 2000). One of the aims of the reforms is to enable the Committee to focus more on strategic issues to guide and reinforce the implementation of the World Heritage Convention.

I.5 He referred to the progress made in revising the Operational Guidelines that was being conducted in a consultative and participatory manner, involving the States Parties, the Advisory Bodies, external experts and the Secretariat. He thanked the members of the Drafting Group and paid tribute to Dr Henrik Lilius (who had chaired the meeting), for having succeeded in accomplishing a colossal task during its meeting from 18 to 22 March 2002. He expressed his hope that the Operational Guidelines and its annexes revised by the
Drafting Group will be examined and approved by the Committee in Budapest.

I.6 Mr Bouchenaki recalled the Committee's request for the Secretariat to provide a legal opinion on the modalities of In-Danger listing and deletion from the World Heritage List. He informed the Bureau that, given the fundamental importance of this mechanism as a tool for international protection under the Convention, the UNESCO Director-General of UNESCO has specifically asked for wide consultation between the World Heritage Centre, the Divisions of Cultural Heritage and Ecological Sciences and the Office of International Standards and Legal Affairs. He noted the Director-General's preoccupation with the far-reaching implications of these issues for the future of the World Heritage Convention and the implementation of other conventions, notably the 1954 Hague Convention, and in shaping the future of other cultural heritage protection treaties in preparation.

I.7 He referred to the need to ensure, through international solidarity, that all the properties inscribed on the World Heritage List are protected and conserved and that the laws and management regimes applied for World Heritage sites will serve as models of good practice to enhance the protection of cultural and natural heritage of national and of local importance.

I.8 In the area of co-operation, he announced the official signature of a framework co-operation agreement between the Agence francaise de développement (AFD) and UNESCO, concluded on 4 March 2002, the negotiation of an agreement between UNESCO and the Japan Bank for International Co-operation (JBIC), and the Japan International Co-operation Agency (JICA) and the development of a more operational and structured relationship with the World Bank for specific cultural heritage projects.

I.9 He also referred to preparations for the Fifth World Congress on Protected Areas to be held in Durban, South Africa in September 2003, the Johannesburg World Summit on Sustainable Development and to the recent organisation of a World Heritage Marine Workshop held in Hanoi, Vietnam in February 2002 financed by the United Nations Foundation.

I.10 The Assistant Director-General for Culture concluded his speech by referring to the Director-General's preoccupation with the current situation in the Middle East. He commented on the importance of protecting the heritage of the region, applying if necessary, the provisions of the 1954 Hague Convention.

I.11 In noting that the protection of heritage is a subject that concerns the entire international community, he referred to his presentation at the United Nations Headquarters on the UN Year for Cultural Heritage for which UNESCO is the lead agency. He called on States Parties, NGOs and others to organize events as part of the 30th Anniversary of the Convention under the theme of partnerships - Shared Heritage, Common Responsibility. 
Finally, he sincerely thanked Hungary for agreeing to host the Committee session in June and wished the Bureau success in its deliberations.

\section{ADOPTION OF THE AGENDA AND TIMETABLE}

II.1 The Bureau adopted the agenda and timetable (WHC-02/CONF.201/1 Rev).

II.2 Following the intervention by Egypt, the Bureau decided to discuss the issue of protection of heritage in the context of the conflict between Israel and Palestine, under Item 16 of the Agenda: Other Business.

\section{NOMINATIONS TO BE EXAMINED BY THE WORLD HERITAGE COMMITTEE IN 2003: STATUS OF NOMINATIONS RECEIVED BY THE WORLD HERITAGE CENTRE}

III.1 The Director of the World Heritage Centre introduced document WHC-02/CONF.201/3, recalling the decision of the 24th session of the Committee (Cairns, 2000) that only "full and complete" nominations that were received by 1 February 2002 would be considered for review by the Committee in 2003. The Director explained the technical evaluation process, calling attention to the definitions given of "full and complete", "almost complete", and "incomplete". Since only seven nominations were "full and complete" by 1 February 2002, meeting all of the requirements of the nomination format, the Centre used the category of "almost complete" under paragraph 65 of the Operational Guidelines to also allow the evaluation of those nominations which only required minor additional information. According to this assessment 26 nominations were either "full and complete" or "almost complete", and were transmitted to the Advisory Bodies for evaluation.

III.2 The Director went on to note that the Committee's decision in Cairns had resulted in an increase in the number of States Parties nominating sites, and that, overall, a wider variety of types of properties have been nominated, potentially contributing to a more balanced and representative World Heritage List.

III.3 Several delegates and observers thanked the Centre for the clear presentation of the working document and implementation of the Committee's decision (Cairns, 2000). The Bureau insisted upon the respect of the date for submission of the inscription of properties. Concern was also expressed that the other part of the Cairns Committee decision, concerning the analysis of sites inscribed on the World Heritage List and the tentative lists, had not been completed.

III.4 While the Committee in Cairns had encouraged States Parties to identify and nominate properties that fell into under-represented categories, it was felt that the delay in preparing the analysis of the World Heritage List and tentative lists had "blocked" States Parties in finalising nominations in potentially under-represented categories.
III.5 In response, ICOMOS recalled that the 24th session of the Committee (Cairns, 2000) had not provided funding for the analysis of the World Heritage List and tentative lists, delaying the start of the project until 2002. Furthermore, despite the complexity of the study, it would be completed by 2003 .

III.6 A delegate asked how the Centre defined categories of completeness of nominations and suggested that the Centre prepare a document on this topic for the Committee session in Budapest (June 2002). The Chairperson supported the Centre's work, indicating that the Centre had done a satisfactory analysis according to the three definitions outlined in the working document.

III.7 The Observer of Argentina sought the views of the Centre on her two following understandings in relation to Document WHC-02/CONF.201/3: a) that, following the presentation of additional information and documentation on the Argentine proposal to inscribe the site "Quebrada de Humahuaca" on the World Heritage List, such nomination was, to this date, "full and complete"; and b) that the presentations made by some countries for future nomination cycles will not affect in any way the possibility of Argentina to make its own proposals in due time. The representative of the Centre agreed with both understandings.

III.8 The Bureau took note of document WHC02/CONF.201/3 and requested the World Heritage Centre to prepare a document for the 26th session of the Committee (Budapest, June 2002) to include reference to the issues discussed by the Bureau. The document is to include a status report and final list of nominations to be examined by the Committee in 2003.

III.9 In a subsequent discussion, the agenda item was reopened at the request of several States Parties. In response to questions, the Director of the Centre outlined the steps taken by the Centre to implement the decision of the 24th session of the Committee (Cairns, 2000) to accept up to 30 "full and complete" nominations received by the 1 February 2002 deadline. He stressed that the Centre had aimed at the maximum possible transparency, and urged that the evaluation of the 26 nominations proceed. At the same time, the Director recalled the recommendation of the Bureau earlier in the session that the issue be presented to the 26th session of the Committee for full discussion.

III.10 While the Bureau acknowledged that the Centre had been transparent in applying the Committee's decision in Cairns, several delegates thought that an interim, phase-out period should have been considered by the Committee to provide for those States Parties who were already preparing nominations, and which were then compelled to change their programme of nominations. One observer noted that a more flexible approach, to give time for States Parties to make "incomplete" nominations into "complete" or "almost complete" nominations was lacking. It was noted that the spirit behind the Cairns decision was to improve the Representivity of the World Heritage List. 
III.11 Another observer recalled that the Cairns decision allied two separate processes: 1) an attempt to limit the workload of the Committee, Advisory Bodies and the Centre by setting an upper limit on the number of nominations it would examine each year, derived from the work of the Task Force on the Implementation of the Convention; and 2) a study of the categories of un- and under-represented properties, which came out of the Working Group on the Representivity of the List. These were linked in Cairns into one decision, but perhaps as several delegates had already noted, the full implications of implementing all elements of the Cairns decision were not foreseen. Furthermore it was noted that the analysis of the List and Tentative Lists by the Advisory Bodies would not necessarily provide the guidance needed. Perhaps the process might benefit from a return to the thematic approach adopted in the 1994 Global Strategy.

III.12 Furthermore, several delegates maintained that under the terms of the Committee's Rules of Procedure, only the Committee could change the Cairns decision, and again agreed that the issue should be brought before the 26th session of the Committee in Budapest.

\section{POLICY/LEGAL ISSUES CONCERNING INSCRIPTION OF PROPERTIES ON THE LIST OF WORLD HERITAGE IN DANGER AND THE POTENTIAL DELETION OF PROPERTIES FROM THE WORLD HERITAGE LIST}

IV.1 The Director of the World Heritage Centre presented document WHC-02/CONF.201/4 that refers to policy/legal issues concerning the inscription of properties on the List of World Heritage in Danger and the potential deletion of properties from the World Heritage List. He explained that in view of the importance of these issues for the future of the implementation of the World Heritage Convention, the Director-General of UNESCO has requested that the document prepared by the UNESCO Secretariat be presented directly to the 26th session of the World Heritage Committee (Budapest, June 2002). This request is based on the consideration that it was the World Heritage Committee that asked for the legal/policy analysis.

IV.2 The Delegate of Greece requested that the document to be presented to the Committee include two options - the possibility of (i) inscription of a property on the List of World Heritage in Danger with the consent of the State Party, and (ii) inscription of a property on the List of World Heritage in Danger without the consent of the State Party.

IV.3 The Bureau took note of document WHC02/CONF.201/4.

\section{ORAL REPORT ON THE PROGRESS FOR THE REVISION OF THE OPERATIONAL GUIDELINES}

V.1 The Chairperson of the World Heritage Committee, presented an oral report on the progress for the revision of the Operational Guidelines. He briefly described the background to the revision process including:

- the decision made at the 23rd session of the World Heritage Committee (Marrakesh, 1999) initiating the revision process;

- the International Expert Meeting on the Revision of the Operational Guidelines (Canterbury, April, 2000) where key recommendations were proposed;

- the preparation of draft revised Operational Guidelines submitted by Australia;

- the decision of the 24th session of the World Heritage Committee (Cairns, 2000) for the establishment of a Drafting Group (held in October 2001); and

- the decision of the 25th session of the World Heritage Committee (Helsinki, 2001) to convene a second Drafting Group (UNESCO Headquarters, Paris, 18 to 22 March 2002) to review the annexes and sections of the Operational Guidelines still requiring finalisation.

V.2 As agreed by the Committee in Helsinki, the March 2002 Drafting Group meeting was attended by cultural and natural heritage experts from the current and former Bureau. An expert from the United Kingdom, representatives of the Advisory Bodies and the World Heritage Centre also participated.

V.3 The revised Operational Guidelines and ten annexes prepared by the Drafting Group will be presented to the 26th session of the Committee (Budapest, June 2002). The Chairperson noted that the legal/policy issues identified by the October 2001 Drafting Group were not discussed at the March meeting as they are issues for the Committee to discuss.

V.4 The Chairperson noted that the Drafting Group strove to make the revised version of the Operational Guidelines more user-friendly and logical for use by the defined target groups. He referred to three additional issues identified by the March 2002 Drafting Group that will need to be discussed by the Committee as follows:

(i) Who can nominate a property to the World Heritage List in the case of an emergency?

(ii) Final wording for criterion (v) and criterion (vi).

(iii) Is a management plan necessary before inscription on the World Heritage List?

V.5 The Chairperson informed the Bureau that the 3rd Draft Annotated Revised Operational Guidelines is currently being compiled and will be translated into French with the assistance of francophone States Parties. 
The revised Operational Guidelines and the report of the Drafting Group, which is also under preparation, will include a clear indication of the issues to be discussed by the Committee. These documents will also be put on the Operational Guidelines web site (whc.unesco.org/opgu).

V.6 Following this presentation. an observer noted that the French and English versions of the Guidelines had not been elaborated simultaneously. She underlined the importance of having a good French translation and requested that both working languages be respected. The Delegate of Egypt also indicated that his country was willing to cooperate in the translation of the revised Guidelines into Arabic, once approved by the Committee. The Director of the World Heritage Centre informed the Bureau that a budget had been approved by the World Heritage Committee (Helsinki, 2001) to cover the translation and dissemination of the revised Guidelines into several languages, as had been the case for the education kit "World Heritage in young hands".

V.7 The Bureau agreed that the definitions of "full and complete", "almost complete" and "incomplete" applied by the World Heritage Centre when determining whether a nomination is suitable for examination by the World Heritage Committee (as referred to in document WHC-02/CONF.201/3), be included in the revised Operational Guidelines.

V.8 The Director of the Centre informed the Bureau that the draft revised Operational Guidelines included a new section on "Protection and Conservation of World Heritage properties" and will incorporate reference to the revised World Heritage meeting schedule and deadlines and other recent reforms approved by the Committee.

\section{WORLD HERITAGE VISUAL IDENTITY AND LEGAL PROTECTION OF THE EMBLEM}

VI.1 A summary presentation was made by the Director of the World Heritage Centre to introduce working document WHC-02/CONF.201/5. He recalled that the purpose of the recommended draft User's Manual and relevant graphic chart (WHC-02/CONF.201/INF.4) was to guide users on how to display the World Heritage emblem on commemorative plaques and other information materials.

VI.2 The Director also specified that this User's Manual was to be considered as a recommended tool to avoid distortions of the original design and meaning of the World Heritage emblem.

VI.3 In addressing the issue of graphic design, the Director drew attention to the proposal contained in the draft User's Manual to jointly display the World Heritage emblem and the UNESCO logo. He considered that the use of both emblems would encourage consistency, increase readability and help improve the presentation of text in different language versions. In addition, the proposal to jointly display both emblems was made in response to the Committee's decision - as reflected in the Guidelines and Principles for the use of the World Heritage Emblem, adopted by the Committee in 1998 and included in the Operational Guidelines - to encourage States Parties to present properties included in the World Heritage List using the World Heritage emblem and the UNESCO logo.

VI.4 Concern was expressed by some members of the Bureau regarding the status of the User's Manual. In responding, the Director of the Centre recalled that the User's Manual was designed in support of the Guidelines and Principles for the use of World Heritage Emblem and did not give any new interpretation of these provisions. Furthermore, he recalled that the User's Manual was still in draft form and had yet to be approved by the Committee before it could be distributed and used.

VI.5 On the issue of legal protection, questions were raised about the procedure through which legal protection of the original World Heritage emblem could be ensured. Clarification was sought as to who had authority to grant the use of the World Heritage emblem, notably in cases where the UNESCO logo and the World Heritage emblem are recommended to be displayed together. The Bureau also asked whether the recommended joint display (presented in WHC-02/CONF.201/INF.4) was to be considered as a new emblem requiring legal protection. Concern was also raised about the use of the UNESCO logo by States Parties to the Convention that are not Member States of UNESCO.

VI.6 In responding, the Legal Advisor confirmed that, although conditions for protecting the World Heritage emblem had not yet been fully outlined, the display of both emblems as shown in WHC-02/CONF.201/INF.4 would not present legal difficulties. He confirmed that the joint display of emblems as a signature would not constitute a new emblem as long as the emblems were not linked to each other. He considered that the decision regarding the use of both emblems in information or communication materials was a matter of policy.

VI.7 He further stated that the use of each emblem, although jointly displayed, would remain under the authority of its statutory body (ie: the Executive Board as concerns UNESCO's logo and the World Heritage Committee for the World Heritage emblem).

VI.8 The Bureau requested that the proposed graphic chart and further information on procedures and costs involved in protecting the original World Heritage emblem be presented to the Committee for consideration. 
VII.

PROGRESS REPORT ON THE ANALYSES
OF THE WORLD HERITAGE LIST AND
TENTATIVE LISTS AND THE
IDENTIFICATION OF UNDER-
REPRESENTED CATEGORIES OF
NATURAL AND CULTURAL HERITAGE

VII.1 The Director of the World Heritage Centre introduced the document WHC-02/CONF.201/6. He informed the Bureau that the Centre had recently met with the Advisory Bodies to review progress with the preparation of the analyses of the World Heritage List and tentative lists.

VII.2 ICOMOS noted that the analyses (as requested by the Committee at its 24th session (Cairns, 2000)) had only recently commenced following the approval of funding by the Committee at its 25th session (Helsinki, 2001). He outlined the procedures being used in the analyses noting that in the first instance a statistical single category analysis was being used. He offered to provide the results of this preliminary analysis to the Bureau. The second phase of the work will include qualitative analyses of the World Heritage List and tentative lists by theme and geographic region. In the third phase national and scientific committees of ICOMOS will be asked to comment on the preliminary results of the analyses.

VII.3 He informed the Bureau that ICOMOS had established a working group to oversee the preparation of the analyses of the cultural properties on the World Heritage List and tentative lists. The working group which had met in March 2002, is chaired by Jean-Louis Luxen (Secretary-General, ICOMOS) and includes the following participants - Georges Abungu (Kenya), Christina Cameron (Canada), Zhan Guo (China), Didier Repellin (France), Francisco Lopez Morales (Mexico), Kevin Jones (New Zealand), Gamini Wijesuriya (Sri Lanka), Christopher Young (United Kingdom), and Henry Cleere, Peter Fowler and Jukka Jokilehto (ICOMOS). The working group has identified the objectives and begun identifying categories for the analyses. A preliminary report will be presented to the 26th session of the Committee (Budapest, June 2002).

VII.4 IUCN informed the Bureau of progress made in the analysis of natural heritage on the World Heritage List and tentative lists. He noted that the methodology and process for the analysis had been defined and that a preliminary report would be submitted to the 26th session of the Committee (Budapest, June 2002). The analysis will use a matrix or multi-factoral approach including reference to themes, biomes and biogeographic realms and provide an indication of gaps of natural heritage in the World Heritage List. The analysis would benefit from the results of the Periodic Reports for the Arab States and Africa, other IUCN studies and reports from thematic World Heritage workshops and would engage the expertise of IUCN's global network of experts.

VII.5 The Deputy Director of the Centre informed the Bureau that the Centre was preparing, in co-operation with
ICOMOS, regional desk studies that analysed the representivity of the heritage of each region on the World Heritage List and tentative lists according to main categories of heritage (type, chronological period, major cultural epochs etc). Desk studies for Asia, for example, had been initiated some years ago within the context of the Global Strategy and preparations for the regional Periodic Reporting exercise. The studies reviewed properties on the World Heritage List and the tentative lists according to major civilizations and epochs using a matrix analysis of categories of heritage. In the future, an analysis of the cultural heritage of minority groups will be made to evaluate their outstanding universal value.

VII.6 The Bureau stressed that the results of the analyses would be an important indication to States Parties as to how they could contribute to improving the representivity and balance of the World Heritage List through the nomination of under-represented categories of heritage.

VII.7 The Bureau requested the World Heritage Centre to prepare a bibliography of existing reports of meetings and the key sources for the analyses. This bibliography should include reference to reports on meetings and studies to harmonise tentative lists since 1984, the proposals for a Global Study in the early 1990s and reports on meetings and studies prepared as part of the Global Strategy since 1994.

VII.8 The Bureau requested the Centre and the Advisory Bodies to prepare a synthesis indicating the proposed contents of the reports of the analyses to be presented to the 26th session of the Committee (Budapest, June 2002).

\section{DISCUSSION ON THE RELATIONSHIP BETWEEN THE WORLD HERITAGE COMMITTEE AND UNESCO}

VIII.1 The Director of the Centre presented the document WHC-02/CONF.201/7. In preparation for the discussion to be held at the forthcoming session of the Committee (Budapest, June 2002), he requested that the Bureau identify any gaps in the document.

VIII.2 The Bureau requested that the document for the Committee be revised to include information on the following:

(i) the relationships (co-ordination, collaboration, communication, roles and responsibilities and objectives) between the World Heritage Centre, the different Sectors and Divisions of UNESCO (including the Culture Sector, the Division of Cultural Heritage, the Science Sector, the Division of Ecological Sciences and the Man and the Biosphere Programme, the Communications Sector and the MOST Programme etc.); 
(ii) the relationships between the World Heritage Committee, the General Conference and the Executive Board;

(iii) the roles and responsibilities of the Secretariat, the World Heritage Committee and the General Assembly of States Parties as indicated in the World Heritage Convention; and

(iv) previous Committee decisions and discussions on this subject (in particular, the 21st session of the Committee (Naples, 1997)).

VIII.3 The Director of the Centre said that the Centre would do its utmost to incorporate the information requested by the Bureau in the document for the 26th session of the Committee. However, he noted that the World Heritage Centre was but a small part of an organisation pursuing a wide array of activities in relation to cultural and natural heritage. The Centre will rely on information provided by the different UNESCO Sectors to prepare the document for the Committee.

\section{PROGRESS REPORT ON THE PREPARATION OF THE PROPOSED STRATEGIC ORIENTATIONS OF THE WORLD HERITAGE COMMITTEE AND REVISED STRUCTURE OF THE BUDGET OF THE WORLD HERITAGE FUND}

IX.1 The Director of the World Heritage Centre presented document WHC-02/CONF.201/8 and requested comments from the Bureau.

IX.2 The Bureau thanked the Centre for the clear and logical structure of the document and made a number of specific proposals to improve the presentation of the summary graphic and the text concerning the strategic objectives (Credibility, Conservation and CapacityBuilding). Some members of the Bureau requested that the first objective be revised to refer to the "Credibility of the List" and not the "Credibility of the Implementation of the Convention". The Bureau also requested that the preparation of the new strategic document include reference to important analyses (for example, analyses of the World Heritage List and tentative lists and the regional Periodic Reports) that should inform the future implementation of the Convention.

IX.3 The detailed comments of the Bureau will be used by the Centre to prepare a revised version of the document for the 26th session of the Committee (Budapest, June 2002).

\section{$\underline{\text { Principles }}$}

IX.4 The Director of the World Heritage Centre introduced the section of the document on "Principles". He referred to two proposals:

(i) the collection of Charters and Recommendations on the protection of cultural and natural heritage of relevance to the implementation of the World
Heritage Convention in a publication and on the World Wide Web as a first step towards the preparation of general guidance on the implementation of the Convention (making reference also to other Charters and Recommendations), and

(ii) the preparation of a set of principles that partners would be asked to accept and adhere to in all of their activities relating to World Heritage.

He stressed that neither of these proposals would involve the drafting of a new charter but rather, would aim to clearly communicate the fundamental principles and philosophies of the Convention.

IX.5 The Bureau expressed its support for the first proposal highlighting the need to communicate and widely disseminate guidance on the protection of World Heritage. ICOMOS noted that it had recently published a compilation of all of the ICOMOS Charters in a publication in English, French and Spanish.

IX.6 The Bureau also emphasised the need to provide guidelines on the post-inscription management of World Heritage properties. In response, the representative of the Centre noted that the revised Operational Guidelines include, for the first time, a distinct section on the Protection and Management of World Heritage properties. At the same time specific management guidelines on the conservation of particular types of World Heritage properties for site managers and others directly involved in conservation of World Heritage properties continue to be prepared (for example, Management Guidelines on World Heritage Cultural Landscapes being prepared by the Advisory Bodies and the Centre). These management guidelines will complement the Operational Guidelines.

IX.7 With reference to the second proposal, the Bureau asked the Centre to identify which partners would be asked to adhere to the principles and to clarify the type of commitment to be elicited from the partners. This will be referred to in the context of the development of selection criteria for the World Heritage Partnerships Initiative.

IX.8 The Bureau requested the Centre, working in cooperation with the Advisory Bodies, to refine the proposal on "Principles" and to develop a calendar and programme of work.

\section{$\underline{\text { Programmes }}$}

IX.9 ICCROM stressed the need for present and future programmes to have clear and well developed strategies. This will enable the Committee to ensure that implementation of individual activities will meet the objectives of the programmes.

IX.10 The Director of the Centre recalled the discussions of the 25th session of the Committee (Helsinki, 2001) concerning the rationale for the establishment of the Programmes. The Programmes aim to 
address global conservation concerns and related management issues through specific site-based activities. The Programme approach will enable methodological coherence, scientific and technical rigour in dealing with conservation issues specific to various categories of properties. Such a framework of priority needs established by the Committee would also support the efforts of the States Parties concerned and the Centre in seeking partners for technical cooperation and financial contributions. The Programmes will thus offer the substance to partnerships where international co-operation can be tangibly put into operation through concrete joint actions among the partners sharing a set of common principles. At the request of the Committee, the Programme activities will also respond to needs identified by the Global Strategy and the regional Periodic Reporting exercise.

IX.11 He stated that the four Programmes which have been initiated with seed funds approved from the World Heritage Fund by the Committee (Helsinki, 2001) are already attracting support from extra-budgetary funding sources as well as from specialized technical bodies, research institutes and universities. He informed the Bureau that a meeting with the Advisory Bodies has been scheduled to enhance co-operation in defining the Programme methodology and areas of technical cooperation.

IX.12 A member of the Bureau questioned the choice of the four thematic programmes (tourism management, conservation of forest sites, conservation management of cities, conservation of earthen structures), stating that the Periodic Reporting exercise in the Arab Region, for example has identified the need for action of greater priority such as the strengthening of heritage protection laws and regulations. An observer stressed the need for the Centre to give greater importance to the analyses of problems and needs rather than to launch into a series of pilot projects.

IX.13 The Deputy Director of the Centre recalled that the selection of the four thematic Programmes was based on the analyses of needs as expressed by the States Parties through international assistance requests and crossreferences with the state of conservation reactive monitoring reports that had been submitted to the Committee. With regard to the vital importance of supporting the strengthening of the regulatory and management framework, she responded that all four Programmes include a review of the protective laws and regulations, especially in relation to the particularity of the type of heritage.

IX.14 The Bureau was informed that other Programmes, also considered to be of priority, were also proposed to the 25th session of the Committee (Helsinki, 2001) and that the Centre would be pleased to develop them if the Committee wishes. The Bureau requested the Centre to provide a summary of the analysis of the needs that served to define the priorities of the four thematic Programmes to the 26th session of the Committee.

\section{Partnerships}

IX.15 The Director of the Centre recalled the discussion on the proposal to develop a World Heritage Partnerships Initiative at the 25th session of the Committee (Helsinki, 2001). The rationale for the initiative is to reinforce the aims of the World Heritage Convention and to increase the resources available to meet long-term conservation goals. The proposal is being developed with reference to the direction of UN-wide policy on partnerships. It will require the appropriate authorisations and approvals.

IX.16 The Director emphasized the need to consider resources in the broadest sense and explained that the proposed initiative was not a fundraising exercise. Potential partners would come from a wide variety of areas - for example universities, local and regional authorities, non-governmental organizations and the media - and provide technical expertise in support of the full range of activities established under the Convention and according to the priorities set by the World Heritage Committee, thereby supporting its work.

IX.17 The Bureau concluded that it is important to define criteria for the selection of partners and the establishment of partnership agreements, thereby facilitating high levels of reporting to the Committee. It would also be critical to obtain the consent of the relevant States Parties to any proposed partnership within the territory concerned. Appropriate communications mechanisms to facilitate two-way flows of information, for example to allow States Parties and local level actors to feed in information, would also need to be developed. The proposal would also need to define the different types of partnerships foreseen, along with control and financial mechanisms.

IX.18 The Bureau requested the Centre to build on the discussions and continue developing the Partnerships proposal which should be presented for discussion by the 26th session of the Committee (Budapest, June 2002). This would include information about existing rules and regulations and an inventory of existing partnerships, which would help define a set of criteria for the selection of potential future partners.

\section{Structure of the budget of the World Heritage Fund}

IX.19 The Director of the Centre recalled that the 25th session of the Committee (Helsinki, 2001) had established a working group to prepare a proposal for a clearer presentation and structure of the budget of the World Heritage Fund. He expressed his interest in receiving the comments of the working group in preparation for the 26th session of the Committee (Budapest, June 2002).

IX.20 The Observer of St Lucia informed the Bureau that the working group had almost finalised the preparation of specific proposals to be submitted to the World Heritage Centre. 
IX.21 The Observer of Argentina requested that the new budget (i) avoid duplication of budget lines, (ii) show other extra-budgetary resources alongside the resources from the World Heritage Fund, and (iii) provide distinct budget lines for each type of International Assistance.

IX.22 The Director of the Centre highlighted two additional budget issues that require the decision of the 26th session of the Committee (Budapest, June 2002):

(i) a review of the budget ceilings for International Assistance (there is now a 10 month period between Committee and Bureau sessions when it may be necessary to provide the Chairperson with greater flexibility to approve International Assistance requests), and

(ii) a potential change in the emergency reserve of the World Heritage Fund.

Proposal to organise an extraordinary session of the World $\underline{\text { Heritage Committee }}$

IX.23 The Chairperson of the Committee convened a private session of the Bureau to discuss progress in the preparation of Committee's new strategic orientations.

IX.24 The Bureau recommended that an extraordinary session of the Committee be convened sometime after the 26th session of the Committee (Budapest, June 2002) to ensure that the Committee could realise its strategic goals. The single item on the agenda would be a discussion on strategic issues. The Bureau agreed that this proposal be made to the 26th session of the Committee for decision. If the Committee decides to convene an extraordinary session it would also define the mandate, precise agenda and timing of the session.

\section{PROGRESS REPORT ON THE PREPARATION OF THE BUDAPEST DECLARATION ON WORLD HERITAGE}

X.1 The Director of the Centre presented the document WHC-02/CONF.201/9. He informed the Bureau that the main objective of the document was to clarify procedural aspects related to the preparation and eventual adoption of the Budapest Declaration.

X.2 A working group open to the participation of all members of the Bureau and observers was established in order to advance the preparation of the Budapest Declaration to be adopted by the 26th session of the Committee in Budapest, June 2002. The Delegate of Hungary informed the Bureau that his country had prepared a preliminary text which would be circulated to Bureau members and which would be the basis for the discussion of the working group established by the present Bureau session.

X.3 The working group met three times and was chaired by the Delegate of Hungary and composed of the delegates and observers from the following States Parties: Argentina, Australia, Belgium, Chile, Finland, Germany, Greece, Israel, Mexico, Portugal, Santa Lucia, Slovakia, South Africa, United Kingdom and the United States of America. Representatives of IUCN, ICCROM and ICOMOS and the World Heritage Centre also participated in the working group.

X.4 The Chairperson of the working group reported to the Bureau on the following proposals concerning the preparation of the Budapest Declaration:

(i) Format and Content:

The working group agreed that the Budapest Declaration should be a short celebratory document with a clear and concrete message. The language should be direct and 'user friendly' allowing the Declaration to be accessible to different and new audiences as a widely used text. The Declaration should be an action-oriented document with short- and long-term objectives being established and with a system being set up for their follow-up and monitoring.

A detailed Action Plan could be annexed to the Declaration that would identify how the Strategic Objectives of the Committee (Credibility, Conservation and Capacity-Building) would be translated into actions. This Action Plan would outline the short- term objectives of the Committee and guide its work in the forthcoming years.

(ii) Objectives:

The working group suggested that the Budapest Declaration provide a broad perspective as to the past and future of the implementation of the World Heritage Convention. The Declaration should serve to increase awareness and support for World Heritage as well as promoting the establishment of new partnerships.

(iii) Target audiences:

The working group agreed that the target audiences of the Budapest Declaration should include new actors who could become involved in the conservation of World Heritage. Emphasis should be placed on promoting further participation from the private sector, local authorities, media and non-traditional decision-makers. The participation of young people should be further encouraged and their views given more consideration.

X.5 The Chairperson of the working group also informed the Bureau on progress made to draft the Declaration. The fourth draft of the Budapest Declaration was circulated to the Bureau prior to the closure of the session. The working group would continue to prepare a draft throughout the forthcoming weeks via exchange of comments through e-mail in order to present the Budapest Declaration for adoption at the 26th session of the Committee. The Working Group considered it important that the Chairperson of the Committee has the opportunity to present the Budapest Declaration to the Venice 
Congress in November 2002. Members of the Working Group thanked the Delegate of Hungary for having led the discussions that had resulted in substantial progress in the development of the draft. The Observer of Argentina requested that the following elements be included in the revised version of the Budapest Declaration:

(i) the universality of the Convention;

(ii) the relevance of the Convention to the well-being of local communities through activities such as sustainable tourism; and

(iii) the new types of heritage.

\section{PROGRESS REPORT ON THE ORGANIZATION OF EVENTS TO CELEBRATE THE 30TH ANNIVERSARY OF THE WORLD HERITAGE CONVENTION IN 2002}

XI.1 The Director of the World Heritage Centre made a brief presentation of working document WHC02/CONF.201/10.

XI.2 He began by recalling that the year 2002 had been designated as International Year for Cultural Heritage by the General Assembly of the United Nations in November 2001 and recommended that the activities proposed for the 30th anniversary of the Convention should also be considered under this heading. He informed the Bureau that a meeting would take place on 10 April 2002 to inform Member States about the UN Year for Cultural Heritage.

\section{$\underline{\text { Part I - Events co-organized by UNESCO }}$}

XI.3 Concerning the 26th session of the Committee (Budapest, June 2002), the Director requested that the Bureau provide guidance to the Centre and the host country Hungary as to how to organize the opening session of the Committee. He recalled that the Bureau had discussed this item during a meeting at UNESCO Headquarters (Paris, January 2002) at which time three suggestions were made as reflected in the working document.

XI.4 Following the recommendation of the Delegate of Hungary, the Bureau agreed on the second option that foresaw the participation of a renowned outside speaker who would be invited to give a keynote address on the Convention. The intervention of this international figure could be complemented by several other shorter presentations to be made by speakers who have been more directly involved in implementing the Convention. As indicated by the Delegate of Hungary, some time may also be allowed to introduce the key elements of the Budapest Declaration.

XI.5 The Director of the Centre then drew attention to the programme outline of the International Congress "World Heritage: Shared Legacy, Common Responsibility" (Venice, November 2002), contained in
Annex 1 of the document. He qualified it as work in progress, frequently being updated as preparations advanced and speakers confirmed their availability to attend. He emphasized the participatory nature of the Congress, pointing to the fact that the Congress was aimed at involving a wide circle of actors involved or potentially interested in joining the conservation efforts promoted by the World Heritage Convention. This would include the involvement of the civil society. He invited the Bureau to suggest ways to ensure the endorsement of the initiative and the participation of the Committee in the International Congress.

XI.6 Concerning the Virtual Congress on World Heritage Management (Oct/Nov 2002), the Director then presented the international seminars organized in the context of the Virtual Congress on World Heritage Management, specifying that the results of these meetings would be relayed via the Internet on a designated web site. He indicated that the seminars would take place in Beijing (China), Alexandria (Egypt), Strasbourg and Paris (France), Dakar (Senegal) and Mexico City (Mexico).

XI.7 The Bureau was supportive of the activities presented, although a number of questions were raised in reference to the International Congress. Concern was expressed regarding the issue of regional and gender representation in the Congress and suggestions were made to encourage the development of regional and national initiatives aimed at celebrating the 30th anniversary of the Convention.

XI.8 Several members of the Bureau asked in what way the Committee would be involved in the preparation of the International Congress. Other questions were posed regarding the category of this meeting (Category IV of the Basic Texts of UNESCO).

XI.9 In response to questions concerning Category IV meetings, the Legal Advisor explained that an International Congress of experts, as defined in the Basic Texts, did not have a mandate to make general policy decisions. He further specified that the work and results of the Congress could be transmitted to the World Heritage Committee, by the Director-General of UNESCO. The Committee could then choose to take them into consideration.

XI.10 Several members of the Bureau suggested to study mechanisms through which the Committee could be involved in the event. In addition, it was proposed that the Chairperson of the Committee should be invited to give a keynote presentation on behalf of the Committee during the opening ceremony of the plenary session. In light of the results of the working group on the Declaration of Budapest, the Bureau recommended that this Declaration be presented by the Chairperson of the Committee during the inauguration of the Congress to serve as a framework for the debate between experts attending the Congress.

XI.11 The Bureau was satisfied that a solution had been found and requested the Centre to revise the programme, 
including a revised list of speakers and expected participants, for submission to the Committee in Budapest.

XI.12 The Bureau expressed its gratitude to the Government of Italy for offering to host and fund the Congress.

XI.13 The Director of the Centre indicated that he would proceed to revise the programme as suggested and would report to the Committee in Budapest as recommended. He further specified that he would consult with the Legal Advisor and the members of the Bureau to propose to the Committee a suitable solution concerning the participation of the Committee members at the Congress.

Part II - Events and activities organized with the support of UNESCO

XI.14 The Director of the Centre informed the Bureau that a number of other activities and events were being organized at regional and national levels by States Parties, Universities and NGOs, and drew attention to the summary list of meetings and seminars contained in the working document. He further indicated that these meetings offered interesting opportunities to promote World Heritage and that the Centre would participate in many of these events.

XI.15 Concerning these events and activities, Observers requested clarification about the nature of UNESCO's involvement in these meetings and asked that States Parties concerned be kept informed of such initiatives. The Director of the Centre indicated that most of these meetings were being organized without the Centre's direct involvement. Nevertheless, information made available to the Centre would be distributed to the Committee.

Part III - Proposal to publish a book to mark the 30th anniversary of the World Heritage Convention

XI.16 The Director of the Centre presented the outline of the publication proposed and concluded by inviting the Bureau to provide comments on this and other activities referred to in the document.

XI.17 Clarification was sought about the choice of themes for the book, the budget and target audience of the publication. A suggestion was made to link this project to the Budapest Declaration, under preparation for examination by the Committee (Budapest June 2002). The Director of the Centre indicated that this project was proposed to reach a wide audience of professionals, students and other parties interested in World Heritage issues. He also informed the Bureau that no definite schedule had yet been set and further specified, that, should the Bureau recommend to commission articles for the book following this session, the publication could be finalised and printed before the end of 2002 .
XI.18 The Bureau recommended that further information be provided to the Committee on the project, notably as concerns its target audience and themes.

\section{REPORTS ON STATE OF CONSERVATION OF PROPERTIES INSCRIBED ON THE WORLD HERITAGE LIST}

\section{General debate}

XII.1 During the debate on the state of conservation of properties, the Observer of Israel pointed out that two issues come up frequently. Many sites seem to have problems with management plans and appropriate protection of the buffer zones. In this respect, he suggested the guidelines be prepared. Furthermore, he noted that the Centre should co-ordinate World Heritage projects with other bodies, such as the World Bank as they seem to be involved in a number of World Heritage sites.

XII.2 The Centre informed the Bureau that such cooperation had improved during the last years and that it was increasingly involved in cultural heritage projects with the World Bank, the Council of Europe and others. The Centre has also been requested to review the new cultural impact assessment policy by the World Bank.

\section{NATURAL HERITAGE}

\section{Asia and the Pacific}

\section{Komodo National Park (Indonesia)}

XII.3 The Bureau noted that a joint UNESCO-UNEPRARE Center for Tropical Conservation mission to the site was fielded, from 23 January to 5 February 2002, as part of the implementation of the UNF-financed project: "Linking Biodiversity Conservation and Sustainable Tourism at World Heritage sites". The State Party informed the Centre that co-operation between Park staff, the Navy and the police has been strengthened considerably and joint patrols are being undertaken. These patrols are likely to help curtail the illegal entry of fishermen from other provinces and nearby islands to exploit the marine areas of the Park; and that discussions regarding the nomination of extensions to the Park for inclusion in the World Heritage site are underway. Furthermore, the extension of the site is in the process of consultation between the central and local governments.

XII.4 The Bureau noted information provided by the State Party and congratulated its efforts to promote cooperation between Park staff, the Navy and the police to strengthen patrolling and surveillance capacity. The Bureau noted that the establishment of a Tourism Concession in support of the management of Komodo National Park required further discussions. The Bureau urged that the Park Management, The Nature Conservancy and other stakeholders study existing legislation and regulations to fully understand the implications of the establishment of the Concession and develop it as a 
support mechanism to provide sustainable revenues for the management of the Park.

XII.5 The Bureau invited the State Party to provide to the 27th session of the Committee, a detailed report on the outcome of these discussions and investigations, as well as on the on-going dialogue between the central and local Governments with regard to the potential extension of the Park boundaries, as a part of the Periodic Reporting Exercise for the Asia Pacific Region.

\section{Royal Chitwan National Park (Nepal)}

XII.6 The Bureau noted that the Department of National Parks and Wildlife Conservation (DNPWC) of Nepal, via a letter dated 22 January 2002, informed the Centre that the Bureau's concerns with the construction of the $33 \mathrm{kv}$ transmission lines between Jagatpur and Madi. This concern had been brought to the attention of the Ministry of Population and Environment, that is responsible for review and approval of the EIA for the project. IUCN has informed the Centre that this EIA is awaiting approval and notes that there is considerable public pressure in favour of the project going ahead.

XII.7 The Bureau also noted that a public hearing on the EIA report of the $33 \mathrm{kv}$ transmission line was held on 24 January 2002. Erection of transmission poles has already begun in Madi and in other parts outside of the northern sector of the Park. People at Madi regard electrification of the area as a step towards their economic prosperity. To date no poles have been erected inside the Park.

XII.8 Concerning the foundation for the Kasara Bridge on the Rapti River, which forms the northern boundary of the World Heritage site, the Bureau noted that it was laid by an earlier Prime Minister in response to requests from the local government and people. It has been reported that alternative sites were assessed as neither suitable nor cost effective for the construction of the bridge. If the bridge is completed and the road is permitted along the bank of the Rapti River, the vehicles using the route will be required to travel at least 4 to 5 kilometres within the Park in order to meet the existing public right of way. The Park authorities believe that it will inevitably cause tremendous pressure on the World Heritage site due to the easy access it will provide.

The Observer of Nepal informed the Bureau that his country has no objection to inviting a monitoring mission to the site.

XII.9 The Bureau expressed its support for measures that would reduce the impact of the transmission line on the World Heritage values of this site and noted that the installation of an underground transmission line, while more expensive, may have the least potential impact on the site. The Bureau urged the Nepal Electricity Authority to consider undertaking all measures to mitigate any significant environmental impacts on the Park, and to contribute to conservation activities in addition to the insulation of the wire along its entire length within the
Park and the buffer zone. The Bureau invited the State Party to undertake an Environmental Impact Assessment of the Kasara Bridge and the associated road in order to identify possible alternatives and/or mitigation measures to minimize the significant negative impacts that are foreseen due to these constructions. Pending the completion of an EIA for the Kasara Bridge construction project, the Bureau recommended that the State Party consider imposing a moratorium on construction and use of the bridge and road.

XII.10 The Bureau requested the State Party to consider inviting a monitoring mission to the site in order to fully assess the impacts of the various development proposals being planned in the vicinity of the Park, and consider alternatives that do not compromise the World Heritage values of the site.

\section{Ha Long Bay (Vietnam)}

XII.11 The Bureau noted that an international expert meeting on the application of the World Heritage Convention in tropical coastal, marine and small-island ecosystems, jointly organized by the Centre and IUCN, was convened in Hanoi and Ha Long Bay from 23 February to 1 March 2002. A Centre staff, as well as several IUCN experts, attended the Workshop and are expected to report back on issues raised by the 25th extraordinary session of the Bureau in December 2001. The report requested from the State Party by the 25th extraordinary session of the Bureau has not been received.

XII.12 IUCN informed the Bureau that the number of caves open to visitation has been reduced, capacities for cave visitation and interpretation have been substantially improved, and the State Party has decided not to open new caves for visitation. Illegal extraction of coral and other forms of sea life for the tourism markets has been halted at the site; however, the collection of cycads and other plants is more difficult to control and still occurs at the site. IUCN noted the number of recent positive measure that should be acknowledged by the Bureau.

XII.13 The Bureau expressed concerns regarding the rapid pace at which developments around this site are being planned and executed while conservation action, such as the implementation of the Government of Vietnam/JICA-sponsored Environmental Management Plan, appears to be rather slow in being launched. The Bureau reiterated its request made at its 25 th extraordinary session in Helsinki that the Government of Vietnam, in collaboration with JICA and other partners as necessary, take urgent steps to implement the recommendations of the Environmental Management Plan without delay. The Bureau invited the State Party to present as a part of the Periodic Reporting Exercise to the 27th session of the Committee (2003), a work plan for the implementation of the Environmental Management Plan for Ha Long Bay. This should include benchmarks that could be used to measure progress in the implementation of the Plan on an annual basis. It was noted that all reports for the Asia 
Pacific region could be provided as part of the Periodic Reporting exercise for this region due in 2003.

\section{Europe and North America}

\section{Pirin National Park (Bulgaria)}

XII.14 As requested by the 25th session of the World Heritage Committee and its Bureau, a joint UNESCO/IUCN monitoring mission was undertaken to the site from 11 to 16 February 2002. The Bureau noted that the full report of the mission is currently being finalized and that it will be presented to the Committee at its 26 th session.

XII.15 The Bureau noted a number of preliminary mission findings and recommendations, in particular that potential threats to the site preceded the current development proposal, the lack of boundary maps and Management Plan at the time of the nomination, as well as the development of a ski area within the site. The new ski development inside the site concerns an additional 29.71 ha of forest disturbance within the 818.46 ha. Furthermore, the Bureau noted that an all-season cable car is proposed. The mission noted that allowing that this development would set a precedent for further ski development proposals and continued erosion of the site. Remediable actions would be required, in particular for effective management controls and reforestation. The Bureau furthermore noted delays in the completion of the Management Plan, and that an 'Interim Plan' is to be prepared to guide development and management of the site.

XII.16 The mission recommended a number of actions to be undertaken by the State Party, including the provision of clarifications and updated information on the approved development, and notice of the conclusion of all appeals, accurate boundary maps of the site of Pirin (1983) showing the existing and proposed ski development areas, the development and adoption of an 'Interim' Management Plan covering management objectives, regulations on development, staffing, visitor use and presentation and the creation of a Scientific Advisory Body for the site of Pirin. The Bureau noted that the State Party already provided detailed information dated 29 March 2002 including a map, an interim report on the status of the management plan and the extension of the site, which will be reviewed by IUCN and the Centre. The Bureau noted that this was a positive step, as the mission had recommended that in case such action is not taken, the Committee may consider inscribing Pirin World Heritage site on the List of World Heritage in Danger.

XII.17 IUCN noted that new ski developments have not been allowed on other sites since their inscription on the World Heritage list. IUCN welcomed the assurance from the State Party that no new ski development would be approved within the site.
XII.18 The Bureau adopted the following recommendation for action by the 26th session of the Committee:

"The Committee notes the results of the report provided by the UNESCO-IUCN mission to the site and the number of existing and potential threats to the values and integrity of the site, including boundary issues, the lack of a management plan, and a new ski development proposal with forest disturbance. The Committee urges the State Party to implement the recommendations of the mission and take remedial actions to ensure that the World Heritage values of the site are protected. These actions should include: the development of effective management controls, reforestation of disturbed areas, the creation of a scientific advisory body and the provision of an interim management plan awaiting the management plan which should be finalized as a matter of urgency. The Committee welcomed the immediate response by the State Party to some of the concerns raised by the mission and invites the authorities to apply for international assistance as indicated in the mission report. The Committee acknowledged the support provided by the State Party of Switzerland for the preparation of the Biodiversity Conservation Management Plan for Pirin National Park and World Heritage site. The Committee may wish to review additional material that may be available at the time of its 26 th session and decide whether or not the conditions of potential threats as indicated in paragraph 83 (ii a, b, d) of the Operational Guidelines would be fulfilled".

\section{Caves of the Aggtelek Karst and Slovak Karst (Hungary/Slovakia)}

XII.19 The Bureau noted that the Minister for the Environment of Slovakia provided a report, dated 30 January 2002, to the Centre that was transmitted to IUCN for review. The report noted that the Minister of Environment, after consultations with the concerned ministries, submitted the proposal to the Slovak Government for designating the Slovak Karst Caves as Slovak Karst National Park, noting that with such a designation the level of protection would increase. The report noted that up to the present, the site has been a Protected Landscape Area where geologic activities and mining have only been allowed with the permission of the nature and landscape protection body. Caves are also protected as "national nature monuments" and afforded the highest level of protection. Further, in 2001 the National Council of the Slovak Republic took all caves into State ownership. To date, no permission has been granted for any geologic or mining activity near the Skalisty potok Kunia preipast cave system. The report also mentioned that the territorial plan of the Large Territorial Unit Kosice Region, approved in 1998 by the Slovak Government, does not propose any limestone mining in the Slovak Karst and emphasises its protection.

XII.20 A number of NGOs, including Sosna, expressed concern that farmers affected by the designation of national park be adequately compensated, is developing, together with the Hrhov local government, proposals for 
development of sustainable tourism and ecological agriculture. The IUCN WCPA Task Force on Caves and Karst commended the excellent standard of administration of cave management, research and monitoring in Slovakia.

XII.21 The Observer of Slovakia informed the Bureau that the new Slovak Karst National Park came into force on 1 March 2002, in a new framework providing protection for natural sites in Slovakia. She underlined that her authorities are working closely with NGOs on these issues to ensure proper consultation and sustainable development in the region.

XII.22 The Bureau commended the State Party on rejecting the mining application that threatened the site, and on the general improvement in legislative control over protected areas and cave systems, as well as for its decision to designate the site as a national park. The Bureau urged the State Party to apply mechanisms that provide for compensation as well as continued community involvement in the management of the national park. The Bureau acknowledged the role of Sosna and its partners in achieving positive outcomes for the protection of the site and encouraged the State Party to carefully consider proposals for sustainable tourism and ecological agriculture in and around the site.

\section{Lake Baikal (Russian Federation)}

XII.23 Following the report of the joint UNESCO/IUCN Monitoring Mission to the site in 2001, presented to the 25 th extraordinary session of the Bureau, and at the request of the 25th session of the Committee, the Permanent Delegation of the Russian Federation transmitted a report on the situation of Lake Baikal dated 1 February 2002.

XII.24 IUCN noted that progress has been achieved in the implementation of a number of measures towards the conservation of Lake Baikal. This was acknowledged in the UNESCO/IUCN report presented to the World Heritage Committee and the efforts of the State Party are recognized in trying to solve the complex conservation issues facing this site.

XII.25 In relation to the report submitted by the State Party the Bureau noted a number of concerns:

1. Baikal Commission: The Bureau welcomed the news, conveyed in the State Party report, of the decision of the Russian Federal Ministry of Natural Resources to establish a Russian Federal Commission for Lake Baikal. However, no information was provided on:

- the time frame to implement this decision;

- when approval could be forthcoming from the Government of the Russian Federation;

- by what process the Commission would be formed;

- the mandate of the Commission;

- who would comprise the Commission and what would be their competencies, and
- when the Commission is expected to be fully operational.

XII.26 IUCN noted that the State Party decision to also create an inter-regional department of the Ministry in the Baikal Region to co-ordinate activities related to nature management and environmental protection in Lake Baikal and adjoining areas, may have the potential to duplicate the role of the Baikal Commission and create confusion.

2. Federal Law "On the Protection of Lake Baikal": This was a key issue raised in the UNESCO/IUCN Monitoring Mission report. IUCN believed that the further specification and follow up of the Law is key to the successful resolution of other problems affecting the site. The State Party report noted that authorities are preparing their suggestions for the delineation of the zones, however that no time frame for final application is given. Though the State Party report noted adoption of several resolutions and legal acts, a clear and logical definition of the borders of the environmental zones is essential.

3. Baikalsk Pulp and Paper Mill: This issue has been brought to the attention of the Committee a number of times and the information received from the State Party confirms its complexity and the need for the Convention to assist the State Party in obtaining additional financial and technical support to solve this problem. The State Party reported that the Expert Commission for the State Environmental Impact Assessment recommended, in mid 2001, that the first stage of the "Complex Program for the Conversion of the Baikalsk Pulp and Paper Mill and Development of the town of Baikalsk" be launched, so as to be completed by 2005 . It remains unclear who will be responsible for implementation of each component of the first stage, and what is the time-table in the short term (1-2 years).

4. Prospects of gas production in the Selenga Delta: The report from the State Party confirmed that there are some geophysical indications of gas deposits in the Delta. IUCN welcomed the information provided by the State Party that the planned drilling of two parametrical wells in the site, to confirm the possibility of gas deposits, is presently subject to a State EIA. IUCN considered that exploration and exploitation of mineral, oil and gas resources is not acceptable within a World Heritage site. IUCN remained concerned that, if the existence of gas deposits is confirmed, exploitation of gas in this area will take place, with associated environmental impacts on the World Heritage site, as outlined in the UNESCO/IUCN Monitoring Mission. IUCN noted that, while the existence of gas deposits in the Selenga Delta is yet to be confirmed, the State Party report does not provide any re-assurance that this resource will not be exploited in the event that its existence and economic viability is confirmed by research.

5. Level of pollution to Lake Baikal through the Selenga River: The report from UNESCO/IUCN Monitoring Mission to this site noted that "the pollution load of the Selenga River is apparently still considerable". 
While IUCN acknowledged, based on the State Party report, that this load has been steadily reduced (by $27 \%$ between 1997 and 2000), the discharge of wastewater to the river in 2000 was still over 60 million cubic metres per annum and this provides a significant impact on the site and remains a major concern. This level of pollution is indeed of concern. IUCN also welcomed the information on the different measures planned to further reduce this level of pollution, however it is not clear from the State Party report what progress had been made in the implementation of these measures, and if the funding received for them is sufficient for full implementation.

6. Single Management Plan for the site: The information received from the State Party noted proposals to develop such a plan under the framework of Article 22 of the Federal Law "On the Protection of Lake Baikal". However, information is required on the resources available to prepare such a plan, and the time frame for this exercise to be completed. IUCN emphasised that the management plan must outline concrete strategies and actions for dealing with threats, in the long, medium and short term.

7. Decline of the Baikal Seal population: The UNESCO/IUCN Monitoring Mission noted a continuous decline in the Baikal seal population. The information provided by the State Party is contradictory to this and to other assessments made available to the team that undertook the UNESCO/IUCN Monitoring Mission in 2001. There is no clear agreement, due to a lack of regular monitoring assessments, on the factors that affect the seal population. IUCN acknowledged that the hunting permits have remained unchanged for the last 8 years (at a level of 3-4 thousands seals per year). However, the UNESCO/IUCN Monitoring Mission noted that the skills of the legal hunters are poor, often causing collateral deaths due to wounding of animals. In the event of a true decline of the seal population due to factors other than hunting, the current level of the legal quota may be inappropriate and create unfavourable pressure on the species. IUCN reiterated the recommendation from the UNESCO/IUCN Monitoring Mission on the need for improved and co-ordinated monitoring of the seal population as well as better training and surveillance of the hunters.

8. Planned oil and gas pipeline to China: IUCN welcomed the commitment from the State Party to require that the EIA prepared by the pipeline contractor should effectively address the protection of the integrity of the site. However, IUCN believed that this issue requires careful attention in the event that important gas reservoirs are found in the Selenga Delta and in the event that the State Party decides to exploit such reservoirs.

9. Pollution from the town of Severobaikalsk: The report of the State Party reinforces the results of the UNESCO/IUCN Monitoring Mission, which noted that the insufficient treatment of sewage remains an issue of serious concern to the integrity of the site.
10. Forest Cutting: The State Party report noted that: wood-logging volumes in the catchment area of Lake Baikal are much lower that they were in the 80's; no clearcutting operations are taking place in the coastal waterprotection zone of Lake Baikal in the Irkutsk Region and the Republic of Buryatia; and all timber is logged under improved environmental felling operations. The UNESCO/IUCN Monitoring Mission also noted official reports that there had been a significant decrease in logging in the Buryat Forest, however the Monitoring Mission report also mentioned that satellite imaging shows that considerable clear-cuttings went on in this area after the inscription of Lake Baikal in 1996. This issue remains unclear.

11. Situation in Pribaikalsky National Park: IUCN welcomed the information provided by the State Party on the increasing level of protection of this national park that has resulted in a decreasing number of violations related to illegal fishing and hunting.

XII.27 IUCN noted that a few issues mentioned in the UNESCO/IUCN Monitoring Mission report were not mentioned in the State Party report: atmospheric pollution; fishing; state of reserves and artificial changes of the water table. With respect to the atmospheric pollution, the UNESCO/IUCN Monitoring Mission report noted the need for improved interpretation of data in order to link monitoring results with sources of pollution. IUCN noted that the conservation and development issues at Lake Baikal are complex and that the positive efforts of the State Party in dealing with these issues are to be commended. IUCN noted there remain some areas of disagreement between the UNESCO/IUCN report and the State Party report.

XII.28 IUCN considered that there remain serious concerns in relation to the state of conservation of this site, particularly in relation to pollution impacts, including from the Baikalsk Pulp and Paper Mill; progress with the Federal Law: "On the Protection of Lake Baikal"; establishment of the Baikal Commission, and uncertainties about gas exploration and exploitation in the Selenga Delta. IUCN thus reiterated the recommendation of the UNESCO/IUCN report to inscribe this site on the List of World Heritage in Danger. IUCN restated that inscription on the List of World Heritage in Danger would be a positive measure to attract international support to enhance the capacity of the State Party to deal with the complex issues related to the conservation of this site. IUCN also reiterated the need to consider the five points proposed to the 25th session of the World Heritage Committee for assessing future progress towards the conservation of this site.

XII.29 The Bureau adopted the following recommendation for action by the 26th session of the Committee:

"The Committee notes that there remain serious concerns in relation to the state of conservation of this site, particularly in relation to pollution impacts, including from 
the Baikalsk Pulp and Paper Mill, the lack of progress with the Federal Law "On the Protection of Lake Baikal", the establishment of the Baikal Commission, and uncertainties about gas exploration and exploitation in the Selenga Delta. Having considered the report provided by the State Party and the comments by IUCN, the Committee decides to include Lake Baikal on the List of World Heritage in Danger.

The Bureau furthermore requested the State Party to provide the following:

- Precise time-schedules for implementation of the first stage of the BPPM Programme in the next 1-2 years;

- Concerning the Baikal Law: a map of the zones, indicating clear and logical borders;

- For the Baikal Commission: documentation detailing the establishment of the co-ordination body, including means of establishment, mandate, composition, date of commencement of duties, competence;

- Concerning the Baikal Seals: information on the training of legal hunters and establishment of a sound monitoring regime; and

- Finally for the Gas Exploration in the Selenga Delta, clear statement of intentions if and when gas is found through "scientific research".

Furthermore, the Committee recommends that regular meetings between the State Party, the UNESCO Moscow Office and IUCN-CIS be encouraged to improve cooperation and communication".

\section{Volcanoes of Kamchatka (Russian Federation)}

XII.30 Following the request by the 25 th session of the Committee, the Permanent Delegation of Russia transmitted a report on the situation of the Volcanoes of Kamchatka, dated 1 February 2002. IUCN noted that the report from the State Party is consistent with IUCN information related to gold mining and the fact that no gas pipeline crosses the territory of the World Heritage site.

XII.31 The State Party reported that salmon poaching in the Kamchatka Peninsula is increasing. However, such activity is being held in check in the protected natural areas included in the World Heritage site due to the operation of special services protecting and controlling the use of water resources, as well as certain environmental protection measures and education. Furthermore, IUCN noted reports of a lack of managerial and staffing levels and capacity in the protected areas, and expressed concern that this affects the ability to control poaching. IUCN acknowledged that hunting is allowed in Bystrinsky Nature Park under National Park regulations, but noted the critical need to develop systems to manage and monitor hunting to avoid reductions in the population of game species. Moreover, IUCN noted that the Bystrinsky Nature Park management does not participate in decisions on the delineation of game areas. There is also concern that current staffing levels inhibit the Park management from effectively monitoring hunting. With respect to the incidence of forest fires, IUCN notes that it continues to receive reports that fires are a problem, and in light of previous comments on staffing levels, is concerned that there is no effective fire management/response system or team. IUCN welcomed the information that the project for the improvement of the Esso-Palana road is to be the subject of a State EIA, however concerns remain on the secondary impacts that this road may have, through the opening up of opportunities for increased poaching and hunting. With respect to the construction of the gas pipeline and geothermal power plant, though both outside the site, it is not clear how far from the boundaries both developments lie. Further details should be requested from the State Party on the construction of the pipeline and geothermal power plant and their Environmental Impact Statements.

XII.32 IUCN welcomed the information that there is no intention to redefine the boundaries of Bystrinski Nature Park beyond the changes undertaken in 1996, and that no gold mining is occurring in the site or adjoining areas.

XII.33 The Bureau noted that there are two GEF-funded projects underway in Kamchatka to address salmon management and to strengthen management of the World Heritage site and welcomed such initiatives. The Bureau requested that the State Party report on any future proposed mining adjacent to the site and the environmental impact assessment process and environmental management measures associated with any such activity. The Bureau noted that there remain some conflicting reports and concerns with the conservation of this site. Therefore, it requested further information on: the management and staffing levels and arrangements in the protected areas comprising the site; the system of delineation or distribution of game areas, and the management of hunting, including the extent of involvement of the protected area management/authorities; and the location of the gas pipeline and power plant in relation to the World Heritage site boundary and any impacts on the World Heritage site. The Bureau decided that a mission to the site, as recommended by the World Heritage Committee at its 25 th session, be deferred until information on the above aspects is received.

\section{Doñana National Park (Spain)}

XII.34 The State Party informed the Centre via letter that its report would only be available after 15 February 2002. The letter notified the Centre of a meeting on 14 February 2002 of the Joint Committee for the Management of Doñana National Park, and the State Party's intention to provide a report on the state of conservation of the site following this meeting. The full report provided by the State Party noted that the project for the proposed expansion of the Port of Seville had not been approved and that it is subject to expert review by stakeholders. Furthermore, progress in the consultation process and institutional arrangements for finalising the new Management Plan and the execution of special plans for the protection of the Iberian lynx and the Imperial Eagle 
(decline of populations due to combination of problems) were noted and that a regional approach is needed. Concerning the illegal water extraction it was stated that actions are taken with the Hydrographical Confederation of Guadalquivir to address this problem. However the Restoration Plan for the Aznalcollar Mine is still to be addressed, as the mine site is releasing a small amount of acid water. Concerning the monitoring of water quality it is noted that water entering the National Park shows minimum levels of pollution. The Restoration Plan requires implementation over a number of years. The Park Administration is exerting increasing control on the Rocío Pilgrimage and environmental education activities are implemented. After the 2nd International Meeting of Project Doñana 2005 (November 2001), a Scientific Committee was created, and a Co-ordinating Commission to link Project Doñana 2005 and the Green Corridor Programme was established. IUCN noted that the situation of the Iberian Lynx has been aggravated, there is a lack of road speed limits and wildlife fatality mitigation infrastructure, and that the pilgrimage is not a single event but a combination of different pilgrimages throughout the year involving $3-5,000$ people and hundreds of vehicles crossing the site. IUCN considered that these pilgrimages could not be considered "traditional" in the way they are occurring. However, the State Party is making concerted efforts and investing substantial funds to address the range of issues affecting the site.

XII.35 The Bureau commended the State Party for its continued efforts towards the conservation of the site. The Bureau noted with concern a number of issues to be addressed including the Iberian Lynx population and the series of pilgrimages through the Park. The Bureau urged the State Party to give priority to promoting integrated regional land-use planning in order to minimise impacts related to irrigation and road design, construction and management around the site.

\section{Giant's Causeway and Causeway Coast (United Kingdom)}

XII.36 A detailed report on the site has been provided via letter and electronic mail from the Department for Culture, Media and Sports dated 11 February 2002. IUCN stated that the report noted that the management plan for the Area of Outstanding Natural Beauty (AONB) which has the World Heritage site as its core, is now under preparation. An issue paper was prepared for public consultation by March 2002, which will be followed by a draft plan in June 2002. A final version of the plan is then to be lodged with the Department of Environment of Northern Ireland (DOENI) in November 2002. DOENI intends to publish the agreed AONB management plan in January 2003. Through the United Kingdom Observer, DOENI undertakes to keep the Bureau informed on progress on the plan.

XII.37 In early 2001, the Moyle Distric Council had offered the site for development. The State Party report noted that a number of planning applications had recently been lodged relating to the area immediately adjacent to the World Heritage site. These applications will be determined under the Northern Ireland planning process. IUCN received some reports expressing concern with threats to the integrity of the site, and more specifically on the following issues: ongoing piecemeal development/applications and poor control on development; absence of an integrated management plan; lack of a statutory development plan which recognises the unique nature of the World Heritage site; concern that the current planning system only considers each application on its own merit, but does not consider cumulative impacts.

XII.38 One of these reports noted that the bid for tender for the visitor centre is the same developer who is already undertaking development in the land adjacent to the site (conversion of a listed building to a public house), and has three other applications pending (Arts, Crafts and Cultural Centre; 60-room hotel and separate tea room). The Bureau noted that the State Party letter of 11 February stated that the decision to sell the land was again reversed by the Moyle District Council on 6 February 2002, and that the Council intended to take the lead in redeveloping the visitor facilities.

XII.39 The Bureau reiterated its concerns about piecemeal development and the absence of a clear buffer zone with special planning provisions that would prevent such development occurring. There is potential for cumulative impacts which could cause irreversible damage to the setting and environmental context of the site. The Bureau noted that the State Party report in December mentioned that the DOENI "has commenced preparation of the Northern Area Plan which will provide the statutory planning framework for development in the area up to 2016. The plan will formulate local planning policies accordingly. As an interim measure, and in advance of the planned adoption of this plan in 2003, the current policy provides for a 4-km radius around the World Heritage site within which all development proposals will be subject to particular scrutiny."

XII.40 The Bureau expressed its concern that knowledge of the two planning processes underway may be intensifying development proposals around the site, and requested information from the State Party as to whether the AONB and normal planning processes provide sufficient protection of the area adjacent to the site. The Bureau encouraged the State Party to delineate a buffer zone as part of the Northern Area Plan and AONB management plan processes. Finally, the Bureau urged the State Party to implement the 4-km special zone during the drafting period of the Northern Area Plan, and to consider a moratorium on commercial development until such time as both the AONB management plan and the Northern Area Plan are further advanced".

\section{St Kilda (United Kingdom)}

XII.41 A detailed report on the site has been provided via letter and electronic mail from the Department for Culture, Media and Sports dated 4 February 2002. IUCN 
noted that the report stated that the results from the seabed survey are being analysed and a report will be produced as soon as possible. These results will inform the development of the proposal for an extension to the $\mathrm{St}$ Kilda World Heritage site as well as providing information for the site to be designated, and therefore protected under European legislation, as a Special Area of Conservation.

XII.42 It is still proposed to complete a consultation draft of the management plan, incorporating both natural and cultural elements of the site. The maritime aspects of the plan will reflect the obligations of the Natural sites that will be able to call on the full backing of legislation to enable enforcement. If the new boundaries extend beyond the six-mile territorial limit this will raise issues relating to the Law of the Sea administered by the International Maritime Organisation.

XII.43 The Observer of the United Kingdom noted that the draft of the management plan will not be ready by June 2002 but needs another year and that her authorities will keep the Centre informed. The Bureau noted that no substantial new information is forthcoming, that the process of producing the management plan is ongoing, and looked forward to the proposals being provided by the State Party.

\section{Latin America and the Caribbean}

\section{Cocos Island National Park (Costa Rica)}

XII.44 The Bureau was informed that after the illegal fishing incident in October 2001 the State Party has undertaken significant actions to increase the protection of the Marine Reserve. These actions include establishing cooperation with the National Coast Guard Service (NCGS) and the Sea Shepherd Conservation Society for patrolling the marine area, extension of the marine limits up to 12 nautical miles and prosecution of illegal fishing boat owners.

XII.45 IUCN congratulated the State Party on the actions taken to protect the site and on the intentions of the State Party to also expand the boundaries of the World Heritage site to match the new marine limits of 12 nautical miles. He informed the Bureau of the proposal for the creation of "Pacific Biological Corridor" between Costa Rica, Ecuador, Colombia and Panamá. The aim of the proposal is to improve the protection of existing protected areas within the Corridor, including two World Heritage sites, namely Cocos Island and Galapagos Marine Reserve, as well as to help prevent marine transportation related accidents and illegal fishing within the region. The proposal is a joint effort between the above-mentioned State Parties, IUCN, Conservation International and UNEP and it is currently being prepared for GEF funding.

XII.46 The Bureau commended the State Party on its efforts to achieve protection of the site with limited resources, and the forming of a strategic partnership with the National Coast Guard Service and Sea Shepherd Conservation Society. It noted that the recent prosecution of the Ecuadorian vessel underlined the commitment of the State Party and sets a precedent for further prosecutions. The Bureau recognised the continuing financial constraints preventing the full enforcement of the present laws and regulations and the courage and dedication of those rangers who have been tackling the poaching threat for years. The Bureau congratulated the State Party on the extension of the Marine Park boundaries to 12 nautical miles, and, in light of the desire of the State Party to extend the boundaries of the World Heritage site to be commensurate with these new boundaries, requested that a proposal be submitted in due course, including a map of the extension. The Bureau fully supported the efforts by The Sea Shepherd Conservation Society, particularly in seeking donations of fast boats, a radar system and other equipment to give to the Cocos Island National Park Ranger Station. If necessary, the State Party may wish to consider requesting additional assistance from the World Heritage Fund.

\section{MIXED (CULTURAL AND NATURAL) HERITAGE}

\section{Tongariro National Park (New Zealand)}

XII.47 The Bureau noted that following the request of the Committee at its 25th session (Helsinki, 2001) the State Party provided a report following completion of a review of the management decisions taken to date to minimise the risks to safety associated with the impending Ruapehu Crater Lake lahar. The Minister of Conservation announced that the installation of a state-of-the-art alarm and warning system, and the construction of a bank alongside the Whangaehu River are sufficient to address risks to public safety from an expected lahar.

XII.48 In addition to these measures, the Department of Conservation is working closely with the Police and the Ministry of Civil Defense and Emergency Management to develop an appropriate emergency response plan. Furthermore, the Ministry is helping organisations with assets in the predicted lahar path to review their individual civil defense response plans.

XII.49 The Minister has decided against undertaking engineering work at the Ruapehu Crater Lake to reduce the impact of a lahar. Such works had been opposed by environmental and recreational groups, the Tongariro/ Taupo Conservation Board, the New Zealand Conservation Authority and by local iwi (Maori tribes). The decision was based on the assessment of potential risks to staff working on the engineering works versus the risk to the public and infrastructure without engineering, and the public concerns about the impact on National Park values that would occur by bulldozing into the summit of the mountain.

XII.50 The decision followed a lengthy period of consultation with technical experts, the community and other stakeholders as well as input from other Government Ministers with portfolios, who would be affected by a lahar. In making the announcement, the Minister stated that an engineering intervention at the Crater Lake would 
be inconsistent with the provisions of the National Parks Act, the Tongariro National Park Management Plan and the World Heritage Convention. "This area is of outstanding international significance for its natural values. Given the high natural values of the Crater and the intense interest in the area," she said, "intervention would have been highly controversial and there would have been considerable uncertainty as to whether the required consents could have been obtained." Both ICOMOS and IUCN have expressed their support for this decision.

XII.51 The Bureau commended the State Party on its decision concerning the management of the ash build-up that has blocked the outlet of Crater Lake following the eruptions of Mount Ruapehu in 1995 and 1996.

XII.52 The Bureau welcomed the decision to install a state-of-the-art alarm and warning system and to construct a bank alongside the Wangaehu River rather than undertake engineering work at the Ruapehu Crater Lake, in the hope that this will maintain the outstanding natural and cultural values of the site whilst giving due regard to public safety issues. The Bureau expressed its hope that all parties will accept the decision.

\section{Hierapolis-Pamukkale (Turkey)}

XII.53 The Bureau noted that a report on the state of conservation of the site was provided by the State Party on 30 January 2002 and was reviewed by IUCN and ICOMOS. The Bureau also noted that since 1992 when the Pamukkale Development Plan was issued, a number of positive developments had occurred:

1. Construction of transportation to the site: the road linking Pamukkale town and the plateau, which climbed through the travertine terraces, has been closed and alternative options are being considered.

2. New access to the terraces is related to the alternative transportation options, which has yet to be resolved.

3. Tourism establishments have been removed from the site and the last two hotels were demolished in 2001 . This is considered one of the major successes of management of the site.

4. Construction of a thermal water distribution network: the development of a thermal water distribution network is almost complete. However the new water distribution channels are visually intrusive and options to address this problem are being considered, including changing the position and level of some channels, or camouflaging the channels with vegetation.

5. Forming new travertine terraces: it is recognized that the major attraction of Pamukkale for tourists is bathing in the terraces. Hence plans are being developed to form new travertine areas to cater to this demand.

6. The report also noted that Pamukkale is part of the World Bank-financed "Turkey: Community Development and Heritage Project", which commenced in 2000. The first activity under this project was an assessment of the 1992 Master Plan.
The assessment concluded that there was an urgent need for the establishment of a proper site management system, together with site interpretation and presentation plan. A Pamukkale Site Management and Presentation Plan is currently being prepared by a joint Ministry of Culture and World Bank team.

XII.54 Although there is still some progress to be made, the Bureau noted that major problems have been resolved and dealt with and there has been a significant improvement in care of the site. Problems relating to the state of conservation of the pools and visitor management have been successfully resolved.

XII.55 The Bureau thanked the Turkish authorities for the detailed report and congratulated them on the measures they have taken to ensure the protection and management of the site. It requested that a report on the progress of the World Bank-financed project be made available and acknowledged the attempts to protect the site from tourist damage through the creation of alternative terraces for bathing. Furthermore, the Bureau urged the State Party to undertake full impact assessments before engaging in any new works, including further access/road construction. It suggested that the State Party seek international technical, scientific and other support to improve the state of conservation of the travertine terraces.

\section{Historic Sanctuary of Machu Picchu (Peru)}

XII.56 The Bureau was informed that the State Party had submitted, on 6 December 2001, a detailed report stating that almost all the recommendations of the 1999 mission had been followed, including a plan for the village of Aguas Calientes, detailed studies on the carrying capacity of, and the means of access to the Sanctuary and its components, the limitation of visitor facilities in the area surrounding the Ciudadela, and the desirability of extending the site. However, from other reports received through the UNESCO Lima Office, gradual deterioration seems to continue.

XII.57 In addition, a "Landslide Risk Mitigation Symposium" took place from 21 to 26 January 2002, at the Disaster Prevention Research Institute of the Kyoto University (Japan) whereby an agreement was reached between the Institute and the Peruvian experts on the process to be followed to continue the research on the Machu Picchu landslide risks.

XII.58 The site has been of serious concern to the World Heritage Committee since 1996. The management arrangements and planning mechanisms for the preservation of the Sanctuary, a proposed cable car from Aguas Calientes to the Ciudadela and a hotel extension, as well as damage to the Intihuantana sundial have been the main motives for this concern.

XII.59 Three monitoring missions have been undertaken to the Historic Sanctuary of Machu Picchu, in 1997, 1999 and 2002, to assess the management and planning of the 
site. The most recent mission was to assess the implementation of the recommendations of the 1999 mission and, in response to damage caused to the Intihuatana sundial, to look into the policy for the commercial use of the site. The mission was undertaken from 25 February to 1 March 2002 and found that only a few of the recommendations of the 1999 mission had been fully implemented:

- Planning and management arrangements for the Sanctuary have improved only marginally and remain inadequate as many stakeholders continue to act in their own self-interest. The strategies of the Master Plan have not been translated into clear planning and action, although an improvement is to be noted in the Operational Plan for the year 2002.

- The Machu Picchu Programme, funded under a debtswap arrangement with Finland, has provided sound information on, and analysis of, many of the critical problems confronting the Sanctuary. However, this information has been used only rarely as the basis for concrete decisions and action.

- Access to the Sanctuary and to the Ciudadela remains as it has been for many years and the contract for the study and eventual construction of the proposed cable car has been cancelled.

- A study on carrying capacity of the Camino Inca has been completed and a regulation for the use of the Inca Trail has been introduced, which is probably the most important progress that has been made in the Sanctuary.

- Terms of reference for development of a Public Use Plan for the Sanctuary are currently being developed in preparation for out-sourcing of this critical work. The Public Use Plan will be pivotal in terms of determining carrying capacities, alternatives for access, and the safety of Aguas Calientes for visitor use. These are critical factors that should be used as the basis for planning visitor services and facilities.

- While urban development and natural disaster mitigation plans have been developed for the village of Aguas Calientes, they have not been implemented nor have their recommendations been followed.

- Scientific and financial support for management of the Sanctuary remains a critical issue for which the Machu Picchu Programme has provided interim solutions, but the Programme will terminate this year. Urgent consideration should be given to the establishment of a permanent, independent, and international institution to provide scientific support to the management of the Sanctuary. There is also a need to immediately establish, as indicated in the Master Plan, a Trust Fund for Machu Picchu, to facilitate the collection, transparent management, and distribution of revenues in accordance with the priorities and strategies outlined in the Master Plan.

- The damage caused to the Intihuantana sundial during filming of a beer commercial has demonstrated that current regulation of commercial use of the site is inadequate. Efforts are underway to augment both regulation and supervision of such activities in the future. Studies have been undertaken that indicate restoration of the damage to be feasible, but little can be done until the legal and administrative processes against the party causing the damage have been resolved. In the meantime, it would be useful to establish a technical commission to study the reports, and make a firm recommendation regarding the restoration.

XII.60 The extensive mission report, to be distributed during the next Committee session, concludes by formulating a series of 38 specific recommendations. On the basis of the findings of the mission and after a brief debate, the Bureau noted the report of the 2002 UNESCOIUCN-ICOMOS mission and its recommendations. While recognising that progress has been made in certain aspects, particularly the management of the Camino Inca, it expressed its very serious concern about the continued inadequacy of the management and planning arrangements for the Sanctuary. The Bureau requested the Chairperson of the World Heritage Committee to write a letter to the highest level competent authorities to invite the Peruvian Government to address these issues as a matter of urgency.

XII.61 The Bureau, furthermore, invited the Government of Peru to consider the report and recommendations of the mission of 2002 and to submit an intermediary response by 15 September 2002, and a full report on the implementation of the recommendations of the missions of 1999 and 2002 by 1 February 2003 for consideration of the Bureau in April 2003.

XII.62 The Bureau requested the Secretariat in cooperation and consultation with the Advisory Bodies concerned, to maintain close communications with and advise the Government of Peru on the implementation of the recommendations of the mission. 


\section{CULTURAL HERITAGE}

\section{$\underline{\text { Arab States }}$}

\section{Byblos (Lebanon)}

XII.63 The Bureau, recalling the recommendations of two Seminars, organized by the World Heritage Centre in 1998 and 1999 in collaboration with the Delft University, noted that Byblos is one of five Lebanese sites considered by a large Cultural Heritage and Urban Development Project financed by the World Bank, and examined the summary of the findings of an ICOMOS mission, carried out to the site in November 2001.

XII.64 An Urban Study was commissioned in 2001 by the World Bank to a Lebanese consultant firm, in preparation for the Project. A preliminary draft report on this Study was presented in November 2001 to the Bank during its pre-appraisal mission, in the presence of a WHC staff member, and discussed later with an ICOMOS expert in the framework of a reactive monitoring mission to the site. The ICOMOS expert examined as well several other proposed developments at the site, and assessed its general state of conservation.

XII.65 Concerning the archaeological area, the Bureau noted that, despite the remarkable efforts of the few staff working at the site, and some cleaning and site presentation carried out in view of the Summit on the Francophonie, most of its monuments and remains are in a very precarious and dangerous state of conservation. The main problems concern exposed and very fragile structures at risk of collapse, unprotected excavations, and the lifted or in situ mosaics, which are being deteriorated by the combined effect of weathering, neglect and cement. The ICOMOS report stressed the urgent need for retaining walls to prevent erosion, the refilling of most open excavations, the conservation and protection of mosaics, and their proper presentation in an exhibition area to be identified.

XII.66 On the World Bank project, the Secretariat explained that it focused on three main areas: access and parking, the historic city centre, and the harbour. The relationship with the archaeological site was not taken into account, and an archaeological study was not commissioned by the Bank, contrary to what was done for Tyre and Baalbek. The Bureau noted, however, that copies of the final studies had so far not been provided to the World Heritage Centre, which therefore could not examine the proposals in detail, but that from discussions with the Consultant, the project did not seem based on a detailed analysis of the ancient topography of the site, including the present-day archaeological area, and appeared conceived on a questionable concept of tourism development. As a result, a number of proposals had raised the concern of the ICOMOS expert. Among these were, for example, the installation of a wooden deck on the coast around the archaeological area with extensions onto the sea; the covering of the pebbly beach below the site with sand and the construction of "adequate services and facilities for a tourist beach"; the re-design of the public square in front of the entrance to the excavations including a new fountain with no relations to the underlying archaeological remains; the construction of a new restaurant and elevated promenade on top of the present souk; the conversion of the Municipality and Old Seray, two of the most significant buildings of the Old City and in direct contact with the archaeological area, into a "Relais et Chateau" type of hotel; the execution of a passerelle around the entire medieval walled enclosure; etc.

XII.67 The Study included as well proposals for the area outside the medieval walls, and especially for the conservation and presentation of the Decumanus Maximus, and its link with a parking area along the present highway on the eastern border of the town. These interventions, which would relieve the old city from excessive traffic and restore the original access to Byblos, were highly recommended by the ICOMOS expert.

XII.68 The Bureau was also informed that the areas immediately to the South and North of the property had not been considered by the World Bank Consultant. However, the ICOMOS Mission learnt of plans to further develop them for tourism purposes, and strongly warned against this idea, lest the encroachment of modern constructions should impact even more on the site and its buffer zone, which remains to be properly defined.

XII.69 On a separate issue, the Bureau noted the proposal by the Lebanese Ministry of Public Works and Transports, for an extension of the new jetty facing the old harbour of Byblos, to protect this and house a small tourist marina. As already pointed out by the participants in the two seminars organized by the Centre, and confirmed by the ICOMOS expert, this extension would have a major negative impact on the old harbour without providing a guarantee against the strong winter currents. The Secretariat then informed the Bureau of a letter, received on 4 April 2002 from the Director-General of the Lebanese Antiquities Department, suggesting an alternative solution to the proposed extension of the jetty, consisting of a breakwater to be executed under the sea, some $200 \mathrm{~m}$ from the old port.

XII.70 The proposed realization of a road across the archaeological area to construct the extension to the jetty, moreover, would be a disaster for the site. ICOMOS strongly recommends that, instead of engaging in these new projects, a detailed survey of the underwater areas around the site and within the harbour be completed as a matter of urgency.

XII.71 The Bureau, furthermore, noted that one of the main problems concerning the archaeological site of Byblos, as much as for all the other archaeological sites of the country, is the chronic lack of staff, which severely affects the capacity of the DGA to adequately conserve and manage this large and very important property. Recognizing this problem at the national level, the World Bank decided to include an Institutional Assessment of the DGA as a precondition for the negotiation of its Project 
with the Lebanese Government. The WHC, which strongly supports this initiative, was involved in the preparation of the Terms of Reference for this Assessment and in the selection of the experts.

XII.72 Finally, the Bureau noted that all these initiatives are being conducted in the absence of a comprehensive Conservation and Management Plan, with specific legal and administrative provisions for its implementation.

XII.73 The Observer of Lebanon informed the Bureau that the final documents and studies prepared by the consultants of the World Bank would shortly be made available to the Secretariat. He also informed the delegates of the intention of the Antiquities Department to request technical assistance from the Centre to assess the feasibility and possible impact of the above-mentioned breakwater. Finally, the Observer of Lebanon agreed on the urgent need for a comprehensive Urban Conservation Plan for Byblos.

XII.74 The Bureau adopted the following recommendation for action by the 26th session of the Committee:

"The Committee commends the State Party for its efforts, undertaken in conjunction with the World Bank for the rehabilitation of the Old City of Byblos and its social and economic revitalization. The Committee, however, expresses concern with regard to some of the proposed interventions, which would be incompatible with the respect for the outstanding universal values of the site. The Committee, furthermore, invites the State Party to ensure that adequate resources, possibly within this Project, be made available to support the necessary conservation and presentation works within the archaeological area, and especially the strengthening of the capacity and number of the local DGA staff.

XII.75 The Committee, therefore, requests the State Party to submit urgently to the Secretariat a complete set of the preparatory studies on Byblos carried out in the framework of the World Bank Project, for examination by the Committee, before a final agreement is reached between the Government of Lebanon and the World Bank on the scope of the activities within this Project.

XII.76 The Committee also invites the State Party to discard plans for an extension of the jetty, and to engage in a thorough investigation of the underwater areas surrounding the site and the harbour. Finally, the Committee encourages the Lebanese authorities to develop a comprehensive Urban Conservation Plan, including provisions for the areas adjacent to the archaeological site, the medieval enclosure, the areas of archaeological potential on the two sides of the Decumanus Maximus, and the zones to the North and South of Byblos, to protect the site and its buffer zones from further encroachments.

XII.77 The Committee strongly encourages the State Party to submit requests for International Assistance under the World Heritage Fund, in addition to the World Bank funding, to accomplish the above-mentioned recommendations, and requests that a report be submitted by the Lebanese authorities on the progress of the situation to the World Heritage Centre by 1 February 2003."

\section{Asia and the Pacific}

\section{Mausoleum of the First Qin Emperor (China)}

XII.78 The Secretariat informed the Bureau on the findings of the mission carried out to the property by a staff of the Centre in November 2001. The property consists of two parts: the Mausoleum mound and, 1.5 kilometers eastward, the Terra Cotta Warriors Museum.

XII.79 The Bureau's attention was drawn to the insufficient co-ordination of site management authorities, uncontrolled tourism development and the lack of a comprehensive management plan to ensure the conservation and sustainable development of this World Heritage property.

XII.80 The Bureau was further informed that major site development and management decisions are being taken without full consultation with the Shaanxi Provincial Cultural Relics Bureau, which had resulted in tourism development being given priority over conservation needs.

XII.81 The Observer of China assured the Bureau that the State Administration of Cultural Heritage and the local governments were placing importance on the management and protection of this site specifically following the recommendations of the UNESCO mission. The Bureau was informed that measures are being taken to expand the boundaries of the property. The Bureau was also assured that intrusive buildings and stands located within the protected core and buffer zones of the site would be relocated. The Observer of China expressed her Government's appreciation to the World Heritage Centre for its support in mobilizing international co-operation and expertise to complement the national and local efforts in safeguarding this important World Heritage property.

XII.82 The Bureau recommended that the Government of China:

- Establish a comprehensive site management authority, which would be supported by both conservation and site development authorities. In particular, the Chinese authorities may wish to draw on the rich experience and human resources of the Shaanxi Provincial Cultural Relics Bureau to ensure that conservation needs are appropriately addressed while developing the site;

- Elaborate a comprehensive management plan for this property, taking into due consideration existing management plans, regulations, heritage protection and preservation needs; 
- Expand the protective buffer zones of the Mausoleum, taking into account the most recent archaeological discoveries and consider relocating intrusive elements beyond the extended World Heritage protective zones;

- Redefine the World Heritage protected core zone of the Terra Cotta Museum complex to include the three pits and identify the rest of the museum complex and its surrounding area as the protected buffer zone with restrictions on new constructions.

XII.83 The Bureau requested the World Heritage Centre to assist the Chinese authorities in the elaboration of a long-term comprehensive management plan for the property. The Bureau further requested that a progress report on measures taken to enhance the conservation and development of the property be submitted for examination by the Committee at its 27 th session, within the framework of the Periodic Reporting Exercise for the Asia-Pacific Region.

\section{Ajanta Caves / Ellora Caves (India)}

XII.84 The Bureau examined the report on the state of conservation of these two World Heritage properties presented in document WHC-02/CONF.201/11Rev and the findings and recommendations of the reactive monitoring mission undertaken by an international mural painting expert undertaken in December 2001. The Bureau noted the following threats facing both properties:

i. infiltration of rainwater into the caves;

ii. minor cracks on carved surfaces;

iii. flaking of the paint layer;

iv. infestation of bats and insects within the caves.

XII.85 The Bureau expressed its appreciation to the authorities of India for their co-operation in the organization of the reactive monitoring mission to the properties. The Bureau urged the authorities to consider the mission's detailed recommendations concerning the conservation, management, and presentation of the properties, by

i. revising present methods for stabilizing and cleaning the wall-painting surfaces;

ii. testing of new and alternative methods on small wall-painting surfaces;

iii. undertaking continuous monitoring of the microclimate conditions in Ajanta Caves;

iv. enhancing documentation and archival material to evaluate changing conditions of the wall-painting material;

v. conserving further, the unique natural setting of the Ajanta and Ellora Caves by following the concept of minimal intervention with the historically established environment and giving preference to conservation solutions which involve minimal changes;

vi. enhancing co-operation between the complementary ASI branches to enhance the long-term protection and conservation of the two sites.

XII.86 Finally, the Bureau requested the World Heritage Centre to continue assisting the authorities of India to mobilize international technical assistance to enhance cooperation between numerous national and international conservation and development activities.

\section{Sun Temple of Konarak (India)}

XII.87 The Bureau examined the report on the state of conservation of this World Heritage property presented in document WHC-02/CONF.201/11Rev. It reiterated its previous requests to the State Party to report on the progress made in developing a comprehensive management plan and on the measures taken in favour of the conservation and development of Konarak. The Bureau encouraged the authorities responsible for the conservation and management of the property to submit an international assistance request to elaborate the Plan for the mitigation of potential threats caused by illegal encroachment and adhoc construction in the areas surrounding the site.

\section{Meidan Emam, Esfahan (Islamic Republic of Iran)}

XII.88 The Bureau examined the report on the state of conservation of this World Heritage property presented in document WHC-02/CONF.201/11Rev and the findings of the World Heritage Centre mission undertaken in January 2002 at the invitation of the Government of Iran. The Bureau noted with appreciation, the high level of conservation of the public monuments composing the Historic Centre of Esfahan, including the Meidan Emam World Heritage area.

XII.89 The Bureau, however, expressed concern over the illegally constructed new commercial complex within the "Conservation Protective Zone of Esfahan Historic City", which replaced a historic caravanserai and negatively impacts upon the skyline of the historic city, as it has been constructed beyond the maximum height limitations for new constructions. Taking note that the Joint Mission to be carried out by an ICOMOS expert and an international urban planner funded under the UNESCO-France Convention was being organized in July 2002, the Bureau requested this Joint Mission to discuss ways and means of minimizing the negative impact of this illegal construction with the concerned authorities during the stakeholders' meeting, also being financed under the UNESCO-France Convention.

XII.90 In the meantime, the Bureau requested the Government of Iran to provide a report on the status of ongoing discussions between the Municipality and the Central Government authorities in correcting the situation, before 25 May 2002, to enable the Committee to examine the case at its 26th session in June 2002. 


\section{Town of Luang Prabang (Lao People's Democratic Republic)}

XII.91 The Bureau examined the report on the state of conservation of this property presented in working document WHC-02/CONF.201/11 Rev.

The Bureau expressed great concern over:

(a) the rapid increase in illegal demolition of historic buildings, including those listed on the inventory of traditional wooden buildings;

(b) the illegal construction of buildings including those of public administrations, in the World Heritage protected area of Luang Prabang, which demonstrates non-respect for the building permit system;

(c) visual impairment and possible engineering problems regarding the Asian Development Bank-financed consolidation works carried out along the banks of the Nam Khan River;

(d) delay in the finalization of the national heritage protection laws and regulations, hence delay in their enactment by the National Assembly of Laos, despite the commitment made by the Government in its letter of September 1995, addressed to the Director-General of UNESCO;

(e) delay in the official adoption by the national authorities of the Luang Prabang conservation plan (Plan de Sauvagarde et de Mise en Valeur-PSMV), also promised in the letter cited above;

(f) lack of progress in the establishment of the subsidy and micro-credit scheme to support the conservation of privately-owned buildings in the historic core; and

(g) non-continuation of consultation process with the local inhabitants, considered essential for the protection of a site largely composed of privately-owned traditional houses.

XII.92 The Bureau, while noting with appreciation the tangible and well-coordinated support provided by the City of Chinon through its decentralized co-operation programme, in partnership with the French Development Agency (AFD), the European Union and the Region Centre amongst others, requested all other national and international actors working in Luang Prabang to ensure that their activities contribute to national capacitybuilding, rather than to the mere completion of the public works. The Bureau reiterated the importance of maintaining the authenticity and the integrity of the town of Luang Prabang, whose World Heritage values are based on the link between the natural and the built environment as well as on the harmonious fusion and co-existence between the traditional Lao and the late 19th-century European urban patterns and the corresponding architectural styles.

XII.93 The Bureau requested the World Heritage Centre to:

(a) arrange for an urgent reactive monitoring mission composed of experts representing ICOMOS and UNESCO with technical competence to evaluate the situation referred to above, including the hydro-engineering problems; (b) organize a technical meeting during this mission with the national and local authorities concerned and with all external and national agencies involved in urban conservation and infrastructure development activities in Luang Prabang, with a view to reinforce co-operation according to a set of defined conservation objectives;

(c) support the State Party in taking immediate measures to halt the process of deterioration to the World Heritage value of the site;

(d) inform the State Party of its deep concern over the nonresponse to its repeated requests for information on the progress in the adoption of legal and management tools in ensuring the protection of this World Heritage site; and

(e) renew its request for a full report on the measures taken to redress the threats, to be submitted to the Centre by 1 February 2003, for examination by the Bureau at its 27th session of the Bureau in April 2003.

\section{Lumbini, the Birthplace of the Lord Buddha (Nepal)}

XII.94 The Bureau examined the report on the state of conservation of this World Heritage property presented in document WHC-02/CONF.201/11Rev and updated information on the on-going consultations between the Nepalese authorities, the World Heritage Centre, the Advisory Bodies and UNESCO international experts concerning the plans for the conservation of the Maya Devi Temple.

XII.95 The Observer of Nepal informed the Bureau that his Government was considering all recommendations of the Committee, its Bureau, its Advisory Bodies and the UNESCO international experts in elaborating its revised proposals for the conservation and presentation of the Maya Devi Temple. He assured the Bureau of his Government's commitment to follow international conservation norms and the recommendation of the World Heritage Committee to ensure appropriate conservation, management, and presentation of this fragile archaeological site that is simultaneously a centre of international pilgrimage.

XII.96 The Bureau, noting that the state of conservation of this property still calls for serious remedial measures based upon careful assessment and analysis of the heritage assets and usage of the pilgrimage property, expressed its appreciation to the Government of Nepal for its willingness to fully co-operate with the Committee, its Advisory Bodies and UNESCO in ensuring the highest level of conservation and presentation of this unique property.

XII.97 In light of the information provided by the Nepalese authorities and the World Heritage Centre concerning the on-going and continuing consultations, the Bureau recommended that the Committee examine further information at its 26 th session.

\section{My Son Sanctuary (Viet Nam)}

XII.98 The Secretariat informed the Bureau that the presence of unexploded ordnance (UXO) at the site, 
following the Vietnam War, has affected the archaeological research of newly-discovered areas, restoration of eight monumental areas, as well as site presentation for visitors. The Bureau noted that the Vietnamese authorities demined unexploded ordnance at four main monuments since 1975. This demining work is progressing slowly, mainly due to lack of funds.

XII.99 The Bureau also noted that, at the request of Vietnamese authorities, the UNESCO Bangkok Office, the Italian Government and the Lerici Foundation carried out a three-year research project (1999--2001) to use noninvasive methods to map the underground archaeological remains of the My Son World Heritage site. Identification of buried structures as well as unexploded mines was completed in 2001. A UNESCO-Italian Funds-In-Trust project (US\$ 812,470) was approved by the Government of Italy in January 2002 in order to facilitate both the demining and restoration work on site. The implementation of this project is being co-ordinated by the World Heritage Centre, in co-operation with the UNESCO field offices in Bangkok and Hanoi.

XII.100 The Bureau expressed its appreciation to the authorities of Vietnam, the UNESCO Bangkok Office, the Lerici Foundation and the World Heritage Centre, for mobilizing the generous contribution of the Government of Italy to enhance the security, management, conservation and presentation of the mined and non-excavated areas of My Son World Heritage site. The Bureau requested the World Heritage Centre to report on the progress made in the implementation of this activity at its 27 th session in April 2003.

\section{Europe and North America}

\section{Classical Weimar (Germany)}

XII.101 In response to an ICOMOS mission to the site in April 2001 to assess the impact of a road project foreseen in the vicinity of the Tiefurt Castle and its Park at Weimar, at which the road proposal (Variant 1) was identified as having the least impact on the site, the progress report provided by the Ministry of Science of the State of Thuringia confirmed that the decision to proceed with the road proposal (Variant 1) had been reached.

XII.102 The Bureau thanked the German authorities for the progress report and congratulated them on the choice of the road proposal (Variant 1) which will have the least impact on the site. It requested the authorities to keep the Centre informed of the progress of this project.

\section{The Curonian Spit (Lithuania/Russian Federation)}

XII.103 The report provided by the Russian Federation on the status of the proposed oil extraction operation by a Russian enterprise in the Baltic Sea stated that the project documentation relating to the development and exploitation of the oil-field had not yet been received by the Russian Federation Natural Resource Ministry. Furthermore, the report stated that at present no oil was being produced and the oil-field did not have a negative impact on the heritage values of the site. The Environmental Impact Assessment (EIA) had not been carried out. It further stated that the buffer zone of the Russian part of the Curonian Spit includes shipping routes of the Baltic Sea and the Curonian Bay at a distance of 1 $\mathrm{km}$ from the coastline, while the oil rig is situated $22 \mathrm{~km}$ from the coast. Within the framework of the RussianLithuanian Joint Committee, acting under the Agreement of co-operation in the field of environmental protection, signed by the two Governments in June 1999, Lithuania may participate in the development of appropriate environmental protection measures to mitigate the possible impact of the oil production on the natural environment, should the decision to start oil extraction be taken.

XII.104 ICOMOS informed the Bureau that the project, although located $22 \mathrm{~km}$ from the site, can be made out from a high point of the Spit. During the ICOMOS-IUCN evaluation mission no mention was made in the documentation of this oil extraction project. ICOMOS pointed out that the potential impact on the site could be catastrophic, and that the strong tides could cause a "black tide" to threaten in particular the Lithuanian part of the Spit. ICOMOS emphasized that effective and extensive measures should be put in place which could come into effect in case of an accident, and that the EIA and protective measures should be carried out jointly by the Lithuanian and Russian authorities.

XII.105 The Bureau took note of the report provided by the Russian authorities and requested the State Party of the Russian Federation to urgently carry out the EIA in collaboration with the Lithuanian authorities. Furthermore, it requested the Russian and Lithuanian authorities to cooperate closely to develop effective and extensive environmental protection measures as a matter of urgency, should oil extraction commence. It requested the State Party of Russian Federation to provide a detailed report on the results of the EIA as well as on progress made in the development of the environmental protection measures by 1 October 2002.

\section{Spišský Hrad and its Associated Cultural Monuments (Slovakia)}

XII.106 The information provided by the State Party stated that the effects of quarrying on the conservation of Spissky Hrad and its Associated Cultural Monuments are negligible. Furthermore, the report pointed out that the quarrying company was elaborating a new extraction and re-cultivation plan, in co-operation with the National Administration for Nature Preservation, in order to meet the criteria for nature and landscape preservation.

XII.107 The Bureau took note of the information provided by the State Party and requested the Slovakian authorities to provide a more detailed report on the situation. This report should include a copy of the new extraction and recultivation plan and an impact assessment, by 1 October 2002 , for examination by the 27 th session of the Bureau in April 2003. 


\section{Stonehenge, Avebury and Associated Sites (United Kingdom)}

XII.108 The report submitted by the Department for Culture, Media and Sports of the United Kingdom informed that management plans are in place for both parts of the site. Concerning Stonehenge, the report stated that an application for planning consent for the visitor centre will be submitted during the summer of 2002 while the highways consent procedure will be initiated in December 2002. Environmental Impact Assessments (EIA) are foreseen for both projects. With regard to Silbury Hill, English Heritage is continuing to make progress in securing its goal of ensuring the long-term conservation of this large prehistoric man-made mound. A programme of on-site works was completed by early October 2001 and involved both the temporary capping of the hole and the execution of a seismic survey of the Hill, with the aim of identifying zones of structural weakness. The survey will provide additional information as to the original construction of the Hill and subsequent archaeological interventions. In addition to the survey work, English Heritage has been carrying out further studies of topographical and written sources and will assess whether any further investigations are necessary and whether further physical works, if any, may be required to ensure the long-term conservation of the Hill.

XII.109 The Bureau noted the information transmitted by the State Party concerning the planning and the protection of the site of Stonehenge as well as the protective works carried out at Silbury Hill. The Bureau congratulated the State Party for the work done on the two management plans of Stonehenge and Avebury respectively. The Bureau expressed its satisfaction regarding the temporary protective works undertaken by the State Party in view of the long-term conservation of Silbury Hill. The Bureau encouraged the State Party to continue the works in close consultation with ICOMOS and the Centre, and requested the authorities to present a progress report in time for its next session in April 2003.

\section{Latin America and the Caribbean}

\section{Historic Centre of the City of Goiás (Brazil)}

XII.110 The Bureau was informed of the damage caused by the flooding of the Historic Centre of Goiás. On the morning of 31 December 2001, Goiás underwent one of its major floods. Starting at dawn, strong intermittent rainfalls brought about an enormous increase in the volume of water drained into the channel of the Rio Vermelho. The site was seriously endangered by these heavy rains and flooding.

XII.111 The inspection carried out by the National Institute for Historic and Artistic Heritage (IPHAN) following the rains and flooding, indicated that :

- the wooden bridge of the Ponte do Carmo was completely destroyed, and those of the Ponte de Lapa and the da Cambaúba were seriously damaged;
- several holes/potholes/craters of considerable size were identified, particularly one next to Cora Coralina's house, close to the Carioca Bridge and another near the Municipality Market Place;

- sections of support walls were destroyed along the riverbank;

- over 80 houses were damaged and a significant number of them were almost totally destroyed;

- among the buildings in the Historic Centre, the Hôpital Sao Pedro, Cora Coralina's House, the Carmel Church, the Sao Joaquim Theatre, the City Hall, the Municipality Market Place and the Bus Station were severely damaged;

- ancient residential and commercial buildings, characterised as vernacular architecture were recorded as cases of total destruction, as well as documents, possessions, equipment, etc.;

- the Cross of Anhanguera, a representative landmark of the City, was partially destroyed.

XII.112 The Director-General of UNESCO visited the site a few days after the flooding. An emergency assistance request amounting to US\$ 57,288 was submitted to carry out exemplary interventions on a dozen vernacular buildings around Cora Coralina's House, the Lapa Bridge and the Cross of Anhanguera. An amount of US\$ 50,000 was already approved by the Chairperson of the World Heritage Committee.

XII.113 Following additional information provided by the State Party, the Bureau requested that a report be submitted by 1 February 2003 on the state of advancement of the restoration works carried out on the property for submission to its 27 th session.

\section{Churches of Chiloé (Chile)}

XII.114 The Bureau noted that on 14 March 2002, a 156 $\mathrm{km} / \mathrm{h}$ wind struck the Grande Island of Chiloé causing important damage to the Churches of Chiloé :

- the tower of the San Juan Church is in danger of collapsing;

- a part of the roof of the Nuestra Gracia de Quinchao Church was blown away as well as four supporting props, and its porch was damaged;

- the tower and the nave of the Tenaún Church is leaning to one side, the foundations of the lateral walls are unstable, the state of the former foundations was not known, this situation is worsened by the high humidity of some of the beams and the presence of wood pests on the ceiling of the central nave;

- the gusts of wind made the tower of the Colo Church lean to one side, and the infiltration caused by the heavy rains have caused humidity at the foot of the beams;

- finally, although the structure of the Nuestra Señora del Rosario de Chonchi Church was considered as being solid, this was the most damaged, losing with the force of the wind alone, its tower which was 
completely blown away. An emergency assistance has been requested from the World Heritage Fund.

XII.115 Following additional information provided by the State Party, the Bureau commended the State Party for the rapidity of its intervention, and requested a detailed report to be submitted to the 26th session of the Committee on the state of the site and the state of advancement of the restoration work being undertaken.

\section{Colonial City of Santo Domingo (Dominican Republic)}

XII.116 The Bureau noted that the State Party's national Bureau for Monumental Heritage provided the World Heritage Centre, on 31 January 2002, with a preliminary report in Spanish (an English translation was subsequently provided on 11 February 2002), on the state of conservation of six colonial houses built by Nicolás de Ovando, siutated in the Historic Centre of the colonial town, as well as the measures which have been undertaken.

1) The national Direction for Heritage met to define a strategy to be followed and to initiative the actions to be undertaken vis-à-vis the occupants renting the buildings, with a view to changing the use of the houses.

2) The work has been temporarily halted. This halt will provide a time for reflection for a new concept of the hotel project that will enhance the use of inner spaces (patios) as links between the buildings.

3) The national Bureau for Monumental heritage has requested the Secretariat of the Environment of the State Party for a report on the impact of the destruction of the sewage system on the urban tissue.

4) New legislation (rules, standards and/or laws) is being formulated, and a draft law for monumental heritage has been finalised.

XII.117 The Bureau requested the State Party to provide a report before 1 February 2003, containing additional information on the progress of the work, the Secretariat of the Environnement's report and on the decisions taken concerning the draft law for monumental heritage, for submission to the 27 th session of the Bureau.

\section{Historic Centre of Lima (Peru)}

XII.118 The Bureau noted the damaged caused by the fire of 29 December 2001, in Lima. The "Mesa redonda" Quarter, densely populated and located in the buffer zone of the Historic Centre of Lima, was severely damaged by fire caused by fireworks. This fire claimed 275 victims, 162 lost and 1000 injured, as well as material damage of US\$ 10,000,000, affecting more than 5000 small enterprises and leaving more than 10,000 jobless.

XII.119 Four blocks of hourses were badly damaged and three others were indirectly affected by flames, smoke and water, in particular the Chinese Quarter situated in the Historic Centre itself. Two buildings of heritage value were destroyed by fire and four others were severely damaged and are presently supported by temporary structures, and risk damaging twelve others.

XII.120 The efforts of the fire-fighters were hampered by defective equipment and almost non-existent preventive measures (absence of emergency exits and local fire fighting equipment). Prior to the fire, the ensemble of the Historic Centre was identified as being located in a highrisk zone. In fact, there is no preventive for natural or man-made catastrophes, whereas almost all the heritage buildings are of wooden construction or made of « quincha » (mixture of mud and branches).

XII.121 Since the fire, the President of the Republic of the State Party has decreed a "state of emergency of the highrisk zone situated in the Historic Centre of Lima". The President has also issued another decree authorising the Ministry of Works and Promotion to approve reconstruction projects of public property in the area of the Mesa redonda. Furthermore, a certain number of emergency measures have been taken by the Minicipality the National Institute for Culture (INC) and the Government, such as:

- clean up of the debris, inventory of damage and loss, reestablishment of $60 \%$ of the services to the affected sector, care of the victims ;

- setting up of an Emergency Operations Committee grouping assistance and obtaining 4,766 signatures of the trades people of Mesa redonda who accept to conform to standard regulations, control and security of their shops. In this regard, it should be emphasized that of the 28 commerical galleries, only 6 had permits in order, and that as of July 2001, fireworks had been forbidden in the Historic Centre.

XII.122 Moreover, during the rehabilitation work, the INC had upgraded the Prehispanic water system, in use until the Colonial period.

XII.123 With the Emergency Assistance of US\$ 48,000 requested from the World Heritage Centre, the Municipality, in co-operation with INC and other national institutions, should develop a safeguarding plan for the disaster area and its surroundings, seeking solutions for the rehabilitation of homes, ensure the systematic updating of safety standards of the trades people, and the implementation of preventive measures for the ensemble of the Historic Centre.

XII.124 After noting additional information provided by the State Party, the Bureau commended the rapid actions undertaken by the State Party following the tragic fire of 29 December. It strongly encouraged the State Party to reinforce its efforts in the implementation of preventive measures against potential natural and man-made risks in the so-called high-risk area of the Historic Centre of Lima. The Bureau also requested the State Party to provide before 1 February 2003 for submission to the 27 th session of the Bureau, a progress report on the measures 
undertaken for the rehabilitation and safeguarding of the site.

\section{Archaeological site of Chavin (Peru)}

XII.125 The Bureau was informed of the conservation difficulties existing at the Archaeological site of Chavin as well as the emergency measures undertaken. These measures concern the immediate halting of earth removal, the underpinning of some walls that risk collapse, the cleaning of ventilation conducts, the establishment of topographical plans to identify water filtration and the development of tourist circuits. The Bureau noted that the members of the Commission for the Chavin Master Plan had been pre-selected and that an enlarged Consultative Committee should define the Management Plan. An expert meeting should be held in May 2002 to assist the Commission for the Chavin Master Plan in defining this Plan.

XII.126 The Observer of Peru provided additional information on the work already undertaken that represents the first phase of a procedure for the Master Plan that will be established taking account of the recommendations made in 1999 by the ICOMOS expert. The second phase will be elaborated and the implementation of the emergency plan, based on an evaluation of the structural stability of the monument for which emergency assistance has been requested. Furthermore, the Observer of Peru confirmed the willingness of the authorities to finalize the Master Plan.

XII.127 The Bureau acknowledged the efforts made by the State Party to preserve the site, in particular through the application of priority actions within an emergency plan. However, the Bureau encouraged the State Party to finalize and implement the Master and Management Plans of the site and requested a detailed progress report by 1 February 2003 for study at its 27th session in April 2003.
XIII. INFORMATION ON TENTATIVE LISTS AND EXAMINATION OF NOMINATIONS OF CULTURAL AND NATURAL PROPERTIES TO THE LIST OF WORLD HERITAGE IN DANGER AND THE WORLD HERITAGE LIST

\section{Tentative Lists}

XIII.1 The Secretariat informed the Bureau that all cultural and mixed sites under consideration are included on the Tentative Lists of the States Parties concerned.

\section{Nomination of properties to the List of World Heritage in Danger}

XIII.2 During the discussion concerning the state of conservation of properties on the World Heritage List, the Bureau recommended that the World Heritage Committee inscribe Lake Baikal (Russian Federation) to the List of World Heritage in Danger.

Examination of a nomination to be processed on an emergency basis to the World Heritage List and to the List of World Heritage in Danger

\begin{tabular}{|l|l|}
\hline Property & $\begin{array}{l}\text { The First Railway Bridge over the } \\
\text { Yenisei River }\end{array}$ \\
\hline Id. $\mathrm{N}^{\circ}$ & $\mathbf{1 0 7 1}$ \\
\hline State Party & Russian Federation \\
\hline $\begin{array}{l}\text { Criteria } \\
\text { proposed }\end{array}$ & C (i) (ii) (iv) \\
\hline
\end{tabular}

By letter dated 29 January 2002 the State Party requested that the nomination of The First Railway Bridge over the Yenisei River be presented this year for inscription on the World Heritage List and on the List of World Heritage in Danger under the provisions of paragraph 67 of the Operational Guidelines.

Additional information was requested from the State Party concerning the urgency of their request. As no information had been received by the World Heritage Centre by the time of the Bureau meeting, the Bureau decided that no emergency nomination procedure could be applied.

Examination of nominations of cultural, natural, and mixed properties to the World Heritage List

XIII.3 Concerning cultural heritage, the Peruvian authorities, via fax received on 15 February 2002 had withdrawn the nomination of the Historic Centre of Trujillo. By a fax received on 8 April 2002, the Italian authorities announced that the mixed nomination of L'Archipel de la Maddalena was being withdrawn, in order to resubmit it at a later time as a cultural landscape. The Secretariat also announced that the Hungarian authorities had withdrawn, on 12 March 2002, the nomination of The Medieval Royal Seat and Parkland at Visegrád. 
XIII.4 The Bureau examined a total of 15 nominations, of which three were for natural properties, one was a mixed property, ten were for cultural properties, and one was an extension to a cultural property.

\section{A. NATURAL PROPERTIES}

\begin{tabular}{|l|l|}
\hline Property & Pendjari and W National Parks \\
\hline Id. $\mathrm{N}^{\circ}$ & $\mathbf{1 0 6 2}$ \\
\hline State Party & Benin \\
\hline Criteria & REFERRED \\
\hline
\end{tabular}

While accepting that the proposed nomination does not meet natural criteria, the Bureau decided that this nomination be referred back to the State Party with the recommendation that it re-submit the nomination as an extension of the existing ' $\mathrm{W}$ ' World Heritage site in Niger seeking the approval of the Niger authorities for this extension.

The Bureau noted that the authorities in Burkina Faso intend to nominate Arli National Park and other areas as a third extension to "W" National Park (Niger) and it would be useful to consider both extension proposals at one time. The Bureau recommended that the three States Parties coordinate the entire tri-national complex as one natural World Heritage property, as encouraged in the Operational Guidelines: "In cases where a cultural and /or natural property which fulfils the criteria adopted by the Committee extends beyond national borders the State Parties concerned are encouraged to submit a joint nomination."

\begin{tabular}{|l|l|}
\hline Property & Rift Valley Lakes Reserve \\
\hline Id. N $^{\circ}$ & $\mathbf{1 0 6 0}$ Rev \\
\hline State Party & Kenya \\
\hline Criteria & REFERRED \\
\hline
\end{tabular}

The Bureau confirmed the 2001 World Heritage Bureau decision to refer this nomination back to the State Party as the gazetting process of one of the reserves, Lake Elmenteita, had not been completed.

The Observer of Israel announced that his country, in October 2002, would host a workshop on the Rift Valley with representatives from the Advisory Bodies and interested States Parties from the region.

The Delegate of South Africa expressed her concern that both African natural site nominations had been referred and hoped that the Centre, the Committee and the Advisory Bodies will collaborate to improve the capacity of the States Parties to respond to the Committee requests.

\begin{tabular}{|l|l|}
\hline Property & Uvs Nuur Basin \\
\hline Id. $\mathrm{N}^{\circ}$ & 769 Rev \\
\hline State Party & Russian Federation / Mongolia \\
\hline Criteria & REFERRED \\
\hline
\end{tabular}

The Bureau referred the nomination back to the State Party of Mongolia with the request that the nominated 'Uvs Lake' protected area cluster be enlarged to include more of the wetlands on the Mongolian side of the TesKhem delta (in the vicinity of the new 'Ubsu-Nur' and 'Oroku-Shinaa' clusters added by the Russian State Party) and that the buffer zones be excluded from the nominated area.

The Bureau commended the States Parties for the development of the two management plans, the signing of transboundary cooperation agreements on scientific research and management, and the steps taken by the Russian authorities to expand the nominated area.

\section{B. MIXED PROPERTIES}

\begin{tabular}{|l|l|}
\hline Property & Saint Catherine Area \\
\hline Id. $\mathrm{N}^{\circ}$ & $\mathbf{9 5 4}$ \\
\hline State Party & Egypt \\
\hline Criteria & C (iii) (iv) (vi) \\
\hline
\end{tabular}

The Bureau recommended to the Committee that this property be inscribed on the World Heritage List on the basis of cultural criteria (iii), (iv), and (vi):

Criterion (iii) St Catherine's Monastery is one of the very early outstanding examples in Eastern tradition of a Christian monastic settlement located in a remote area. It demonstrates an intimate relationship between natural grandeur and spiritual commitment.

Criterion (iv) Ascetic monasticism in remote areas prevailed in the early Christian church and resulted in the establishment of monastic communities in remote places. St Catherine's Monastery is one of the earliest of these and the oldest to have survived intact, being used for its initial function without interruption since the 6th century.

Criterion (vi) The St Catherine's area, centred on the holy mountain of Mount Sinaï (Jebel Musa, Mount Horeb), like the Old City of Jerusalem, is sacred to three world religions: Christianity, Islam, and Judaism.

The Bureau discussed the possible use of criterion (i) for this property, but concluded that it should not be applied.

The Bureau also recommended that the Committee request the State Party to consider the recommendations contained in the ICOMOS evaluation, particularly the need to prepare a visitor management plan for the monastery and the implementation of the 1998 sustainable development plan for the town of St. Catherine. The State Party should report on progress in these areas to the Committee in the year 2004. 
The State Party welcomed the Bureau's recommendation, noting that during his visit, the Pope had emphasized the importance of this site towards furthering understanding between the different faiths. The spiritual importance of this property as a meeting point for followers of the three Great Monotheistic religions, Christians, Muslims and Jews was stressed. If the Committee decides to inscribe the property it should take the opportunity to publicize the message of peace of the World Heritage Convention.

\section{CULTURAL PROPERTIES}

\section{C.1. ARCHAEOLOGICAL SITES}

\begin{tabular}{|l|l|}
\hline Property & $\begin{array}{l}\text { The Ancient Maya City of } \\
\text { Calakmul, Campeche }\end{array}$ \\
\hline Id. $N^{\circ}$ & $\mathbf{1 0 6 1}$ \\
\hline State Party & Mexico \\
\hline Criteria & C (i) (ii) (iii) (iv) \\
\hline
\end{tabular}

The Bureau recommended to the Committee that this property be inscribed on the World Heritage List on the basis of cultural criteria (i),(ii), (iii) and (iv):

Criterion (i) The many commemorative stelae at Calakmul are outstanding examples of Maya art, which throw much light on the political and spiritual development of the city.

Criterion (ii) With a single site Calakmul displays an exceptionally well preserved series of monuments and open spaces representative of Maya architectural, artistic, and urban development over a period of twelve centuries.

Criterion (iii) The political and spiritual way of life of the Maya cities of the Tierras Bajas region is admirably demonstrated by the impressive remains of Calakmul.

Criterion (iv) Calakmul is an outstanding example of a significant phase in human settlement and the development of architecture.

After some discussion on the application of criterion (i), the Bureau left the final decision on its application to the Committee.

\section{C.2. HISTORIC TOWNS}

\begin{tabular}{|l|l|}
\hline Property & $\begin{array}{l}\text { Historic Centres of Stralsund and } \\
\text { Wismar }\end{array}$ \\
\hline Id. $N^{\circ}$ & $\mathbf{1 0 6 7}$ \\
\hline State Party & Germany \\
\hline Criteria & C (ii) (iv) \\
\hline
\end{tabular}

This nomination is for the historic centres of two 14thcentury Hanseatic cities on the Baltic Sea.

\begin{tabular}{|c|c|c|}
\hline Historic Town Centre & Area & Buffer Zone \\
\hline Straslund & 80 ha & 340 ha \\
\hline Wismar & 88 ha & 108 ha \\
\hline Total & $168 \mathrm{ha}$ & 448 ha \\
\hline
\end{tabular}

The Bureau recommended to the Committee that this property be inscribed on the World Heritage List on the basis of cultural criteria (ii) and (iv):

Criterion (ii) Wismar and Stralsund, leading centres of the Wendish section of the Hanseatic League from the 13th to 15th centuries and major administrative and defence centres in the Swedish kingdom in the 17th and 18 th centuries, contributed to the development and diffusion of brick construction techniques and building types, characteristic features of Hanseatic towns in the Baltic region, as well as the development of defence systems in the Swedish period.

Criterion (iv) Stralsund and Wismar have crucial importance in the development of the building techniques and urban form that became typical of the Hanseatic trading towns, well documented in the major parish churches, the town hall of Stralsund, and the commercial building types, such as the Dielenhaus.

The Bureau also recommended that consideration be given to the possibility of inscribing the historic towns of Stralsund and Wismar as a serial nomination together with Lübeck and for a joint name for such a site. All three towns were leading centres in the Wendish region of the Hanseatic League in northern Germany, representing complementary aspects in terms of trading, production of goods, and the typology of constructions.

The Bureau recommended that special attention be given to the regulation of the design of modern details and the appropriate use of materials and technology in the rehabilitation of historic structures. The height and design of any new building or addition considered as essential within the historic core area and in its surroundings should respect the traditional skyline and character of the historic town.

\begin{tabular}{|l|l|}
\hline Property & $\begin{array}{l}\text { Andrássy Avenue and the } \\
\text { Millennium } \\
\text { (extension to "Budapest, the Banks } \\
\text { of the Danube and the Buda Castle } \\
\text { Quarter") }\end{array}$ \\
\hline Id. $\mathrm{N}^{\circ}$ & $\mathbf{4 0 0}$ Bis \\
\hline State Party & Hungary \\
\hline Criteria & C (ii) (iv) \\
\hline
\end{tabular}

The proposed extension would add 57.85 ha to the existing World Heritage property:

\begin{tabular}{|l|l|l|l|}
\hline Date & Name & Area & $\begin{array}{l}\text { Buffer } \\
\text { Zone }\end{array}$ \\
\hline $\begin{array}{l}1987 \\
\text { Inscribed }\end{array}$ & $\begin{array}{l}\text { Budapest, the Banks of } \\
\text { the Danube and the } \\
\text { Buda Castle Quarter }\end{array}$ & $400.00 \mathrm{ha}$ & \\
\hline $\begin{array}{l}2002 \\
\text { proposed }\end{array}$ & $\begin{array}{l}\text { Andrássy Avenue and } \\
\text { the Underground }\end{array}$ & $57.85 \mathrm{ha}$ & $239.61 \mathrm{ha}$ \\
\hline
\end{tabular}

The Bureau recommended the approval of the extension to the existing World Heritage Site, "Budapest, the Banks of 
the Danube and the Buda Castle Quarter" (inscribed in 1987), using the existing cultural criteria (ii) and (iv).

The Bureau recommended that the buffer zone be extended to the western side of the existing World Heritage site, on the Buda side of the town.

\begin{tabular}{|l|l|}
\hline Property & $\begin{array}{l}\text { The Late Baroque towns of the Val } \\
\text { di Noto (South-eastern Sicily) }\end{array}$ \\
\hline Id. $\mathrm{N}^{\circ}$ & $\mathbf{1 0 2 4}$ \\
\hline State Party & Italy \\
\hline Criteria & C (i) (ii) (iv) (v) \\
\hline
\end{tabular}

This serial nomination concerns eight towns in the southeast of Sicily that were all rebuilt immediately following the catastrophic earthquake of 1693.

\begin{tabular}{|c|c|c|c|}
\hline Town & Province & Area & $\begin{array}{l}\text { Buffer } \\
\text { Zone }\end{array}$ \\
\hline Caltagirone & Catania & 22.68 ha & $49.04 \mathrm{ha}$ \\
\hline Catania & Catania & $38.50 \mathrm{ha}$ & \\
\hline Militello Val di Catania & Catania & & \\
\hline Modico & Ragusa & $18.00 \mathrm{ha}$ & \\
\hline Noto & Siracusa & 75.75 ha & \\
\hline Palazzolo Acreide & Siracusa & 1.00 ha & 56 ha \\
\hline Ragusa & Ragusa & 60.00 ha & \\
\hline Scicli & Scicli & $4.00 \mathrm{ha}$ & \\
\hline & $\begin{array}{l}\text { TOTAL } \\
\end{array}$ & $219.93 \mathrm{ha}$ & \\
\hline
\end{tabular}

The Bureau recommended to the Committee that this property be inscribed on the World Heritage List on the basis of cultural criteria (i), (ii), (iv), and (v):

Criterion (i) This group of towns in south-eastern Sicily provides outstanding testimony to the exuberant genius of late Baroque art and architecture.

Criterion (ii) The towns of the Val di Noto represent the culmination and final flowering of Baroque art in Europe.

Criterion (iv) The exceptional quality of the late Baroque art and architecture in the Val di Noto lies in its geographical and chronological homogeneity, as well as its quantity, the result of the 1693 earthquake in this region.

Criterion (v) The eight towns of south-eastern Sicily that make up this nomination, which are characteristic of the settlement pattern and urban form of this region, are permanently at risk from earthquakes and eruptions of Mount Etna.

The State Party agreed with the proposal of ICOMOS to a change in the name of property to: "The Late Baroque towns of the Val di Noto (South-eastern Sicily)."

\begin{tabular}{|l|l|}
\hline Property & $\begin{array}{l}\text { Portuguese City of El Jadida } \\
(\text { Mazagan) }\end{array}$ \\
\hline Id. $\mathrm{N}^{\circ}$ & $\mathbf{1 0 5 8}$ \\
\hline State Party & Morocco \\
\hline Criteria & DEFERRED \\
\hline
\end{tabular}

While recognizing the outstanding universal value of the proposed nomination, the Bureau decided that further consideration of this nomination be deferred subject to the redefinition of the site to include the whole area of the defensive system (the ditches), the extension of the buffer zone, the completion and implementation of the management plan and conservation guidelines for the site, and the establishment of planning control for the surrounding area, including the clarification of the impact of proposed new development near the fortification.

Taking into account that the present nomination is limited to the Portuguese fortification of Mazagan, consideration should be given to the possibility of changing the name: "The Portuguese City of Mazagan (El Jadida)."

\begin{tabular}{|l|l|}
\hline Property & $\begin{array}{l}\text { The Historic Inner City of } \\
\text { Paramaribo }\end{array}$ \\
\hline Id. $\mathrm{N}^{\circ}$ & 940 Rev \\
\hline State Party & Suriname \\
\hline Criteria & C (ii) (iv) \\
\hline
\end{tabular}

The Bureau recommended to the Committee that this property be inscribed on the World Heritage List on the basis of cultural criteria (ii) and (iv):

Criterion (ii) Paramaribo is an exceptional example of the gradual fusion of European architecture and construction techniques with indigenous South America materials and crafts to create a new architectural idiom.

Criterion(iv) Paramaribo is a unique example of the contact between the European culture of the Netherlands and the indigenous cultures and environment of South America in the years of intensive colonization of this region in the 16 th and 17 th centuries.

Some discrepancies were noted in the text of the paragraph "conservation and authenticity" of the ICOMOS evaluation. The Chairperson agreed that this should be rewritten by ICOMOS for the next Committee session.

\section{C.3. RELIGIOUS PROPERTIES}

\begin{tabular}{|l|l|}
\hline Property & $\begin{array}{l}\text { The Mahabodhi Temple Complex } \\
\text { at Bodh Gaya }\end{array}$ \\
\hline Id. $\mathrm{N}^{\circ}$ & $\mathbf{1 0 5 6}$ Rev \\
\hline State Party & India \\
\hline Criteria & C (ii) (iii) (iv) (vi) \\
\hline
\end{tabular}

The Bureau recommended to the Committee that this property be inscribed on the World Heritage List on the basis of cultural criteria (ii), (iii), (iv) and (vi) : 
Criterion (ii) The Mahabodhi Temple, one of the few surviving examples of early brick structures in India, has had significant influence in the development of architecture over the centuries.

Criterion (iii) The site of the Mahabodhi Temple provides exceptional records for the events associated with the life of Buddha and subsequent worship, particularly since Emperor Asoka built the first temple, the balustrades, and the memorial column.

Criterion (iv) The present Temple is one of the earliest and most imposing structures built entirely in brick from the late Gupta period. The sculpted stone balustrades are an outstanding early example of sculptural reliefs in stone.

Criterion (vi) The Mahabodhi Temple Complex in Bodh Gaya has direct association with the life of the Lord Buddha, being the place where He attained the supreme and perfect insight.

Taking note of the ambitious initiatives for the presentation of the site, the Bureau drew the attention of the responsible authorities to the need to continuously monitor the impact that such challenges may have on the religious and spiritual significance of the place.

\begin{tabular}{|l|l|}
\hline Property & $\begin{array}{l}\text { Wooden Churches of Southern } \\
\text { Little Poland }\end{array}$ \\
\hline Id. N & $\mathbf{1 0 5 3}$ \\
\hline State Party & Poland \\
\hline Criteria & C (iii) (iv) \\
\hline
\end{tabular}

The Bureau recommended to the Committee that the six medieval wooden churches of Binarowa, Blizne, Debno, Haczow, Lipnica Murowana, and Sekowa be inscribed on the World Heritage List on the basis of cultural criteria (iii) and (iv):

Criterion (iii) The wooden churches of Little Poland bear important testimony to medieval church building traditions, as these related to the liturgical and cult functions of the Roman Catholic Church in a relatively closed region in central Europe.

Criterion (iv) The churches are the most representative examples of surviving Gothic churches built in horizontal log technique, particularly impressive in their artistic and technical execution, and sponsored by noble families and rulers as symbols of social and political prestige.
The following six churches are proposed in this serial nomination:

\begin{tabular}{|l|l|r|r|}
\hline Church & Town & \multicolumn{1}{|c|}{$\begin{array}{l}\text { Area } \\
\text { (ha) }\end{array}$} & $\begin{array}{l}\text { Buffer } \\
\text { Zone }\end{array}$ \\
\hline $\begin{array}{l}\text { Church of the Archangel } \\
\text { Michael }\end{array}$ & Binarowa & 1.80 & 40.4 \\
\hline Church of All Saints & Blizne & 2.20 & 46.7 \\
\hline $\begin{array}{l}\text { Church of the Archangel } \\
\text { Michael }\end{array}$ & Dębno & 0.14 & 64.0 \\
\hline $\begin{array}{l}\text { Church of the Assumption of } \\
\text { the Blessed Virgin Mary and } \\
\text { the Archangel Michael }\end{array}$ & Haczów & 1.30 & 38.2 \\
\hline $\begin{array}{l}\text { Church of St Leonard } \\
\text { Church of St Philip and St } \\
\text { James the Apostles }\end{array}$ & Lipnica & 1.10 & 16.5 \\
\hline \multicolumn{2}{|c|}{ Turowana } & 1.72 & 36.4 \\
\hline
\end{tabular}

The Bureau considers this to be the first element of a serial inscription, to be completed when the comparative study of medieval wooden churches in Hungary, Romania, Slovakia, and Ukraine has identified additional properties in those countries.

The Bureau urged the State Party as a matter of priority to monitor and, where necessary, update the fire prevention facilities at all the churches. The Delegate of Finland called attention to fire prevention measures adopted for wooden churches in Scandinavia and recommended that the authorities in the two regions consult on common solutions.

\section{C.5. CULTURAL LANDSCAPES}

\begin{tabular}{|l|l|}
\hline Property & Upper Middle Rhine Valley \\
\hline Id. $N^{\circ}$ & $\mathbf{1 0 6 6}$ \\
\hline State Party & Germany \\
\hline Criteria & C (ii) (iv) (v) \\
\hline
\end{tabular}

ICOMOS informed the Bureau that new information was made available and recommended the site for inscription. A delegate noted that ICOMOS had changed its recommendation concerning this site between the date of the document preparation and the Bureau session and that texts for the recommendation and criteria were not available for discussion by the Bureau.

The Bureau recommended to the Committee that this property be inscribed on the World Heritage List on the basis of cultural criteria (ii), (iv) and (v) :

Criterion (ii) As one of the most important transport routes in Europe, the Middle Rhine Valley has for two millennia facilitated the exchange of culture between the Mediterranean region and the north.

Criterion (iv) The Middle Rhine Valley is an outstanding organic cultural landscape, the present-day character of which is determined both by its geomorphological and geological setting and by the human interventions, such as settlements, transport 
infrastructure, and land-use, that it has undergone over two thousand years.

Criterion ( $v$ ) The Middle Rhine Valley is an outstanding example of an evolving traditional way of life and means of communication in a narrow river valley. The terracing of its steep slopes in particular has shaped the landscape in many ways for more than two millennia. However, this form of land-use is under threat from the socio-economic pressures of the present day.

\begin{tabular}{|l|l|}
\hline Property & $\begin{array}{l}\text { Tokaji Wine Region Cultural } \\
\text { Landscape }\end{array}$ \\
\hline Id. $\mathrm{N}^{\circ}$ & $\mathbf{1 0 6 3}$ \\
\hline State Party & Hungary \\
\hline Criteria & C (iii) (v) \\
\hline
\end{tabular}

The Tokaji Wine Region is a serial nomination of a core area and two historic cellars in towns 20 and $30 \mathrm{~km}$ northeast of the core area.

\begin{tabular}{|c|c|c|c|}
\hline Site & Towns & Area & $\begin{array}{l}\text { Buffer } \\
\text { Zone }\end{array}$ \\
\hline $\begin{array}{l}\text { Tokaji Wine } \\
\text { Region }\end{array}$ & $\begin{array}{l}\text { Tokaj, Bodrogkeresztúr, } \\
\text { Bodrogkisfalud, Mád, } \\
\text { Mezozombor, Rátka, } \\
\text { Szegi, Tarcal, Tállya }\end{array}$ & 13,245 & \multirow[t]{3}{*}{$74,879 \mathrm{ha}$} \\
\hline Ungvári Cellar & Sátoraljaújhely & 4.0 & \\
\hline Rákóczi Cellar & Sárospatak & 0.8 & \\
\hline & TOTAL AREA & 13,255 ha & 74,879 ha \\
\hline
\end{tabular}

The Bureau recommended to the Committee that this property be inscribed on the World Heritage List on the basis of cultural criteria (iii) and (v):

Criterion (iii) The Tokaji wine region represents a distinct viticultural tradition that has existed for at least a thousand years and which has survived intact up to the present.

Criterion (v) The entire landscape of the Tokaji wine region, including both vineyards and long established settlements, vividly illustrates the specialized form of traditional land-use that it represents.

The Bureau had a lengthy debate on the question of thematic and comparative studies. A number of Delegates considered that the State Party should not be penalized by the fact that ICOMOS has not yet commenced the Global Vineyard Study as requested by the Committee. Other Delegates and Observers raised the question of consistency, as the Alto Douro Wine Region had been inscribed at the last session of the Committee without the Global Study being available.

IUCN commented that Thematic Global Studies are essential as a basis for objective and coherent decisions.

A number of delegates queried whether the site could be a transboundary one with Slovakia or whether at a later stage it might be extended to include the Slovakian side.
ICOMOS reported that no site visit to Slovakia had taken place and that no nomination dossier has been presented by the State Party so far.

After the decision by the Bureau to recommend inscription, the Chairperson invited both Hungary and Slovakia to comment.

The Delegate of Hungary thanked the Bureau and stated that his country is open to cooperation with Slovakia in the event that a future nomination was to be submitted by this country.

The Observer of Slovakia informed the Bureau that her country gives priority to Tokaij in its Tentative List and is preparing a nomination in conformity with the Operational Guidelines. It attaches high importance to a transboundary nomination of Tokaji by Hungary and Slovakia, as it is an integral vineyard area by reason of the wine tradition, soil and climate. Her country as part of Czechoslovakia registered the "appellation d'origine" of Tokaj wine in 1967 at the World Intellectual Property Organization, whereas Hungary did so in 1970. She welcomed the recommendation of the World Heritage Thematic expert meeting on Vineyard Cultural Landscapes on the importance of the coherent delimitation of vineyard cultural landscapes based on geographical units and historical territories, with reference to the "appellation d'origine controlée". She also made a reference to the ICOMOS recommendation with respect to the unilateral Tokaj nomination of Hungary.

The Chairperson encouraged the two States Parties to work together towards the inscription of a future transboundary site.

A delegate encouraged ICOMOS to take into account in its Global Study the question of wine production by autochthonous populations, as was the case in Europe, and vineyards elsewhere, which were started by immigrants to the Americas, Africa and Australia, in different sociocultural and environmental contexts. An observer suggested that States Parties should refrain from presenting vineyard nominations until ICOMOS has provided this Global Study.

An observer requested the Centre and ICOMOS to provide indispensable complementary information to enable the Committee in Budapest to take decisions.

\begin{tabular}{|l|l|}
\hline Property & $\begin{array}{l}\text { The Sacri Monti of Piedmont and } \\
\text { Lombardy }\end{array}$ \\
\hline Id. $\mathrm{N}^{\circ}$ & $\mathbf{1 0 6 8}$ \\
\hline State Party & Italy \\
\hline Criteria & C (ii)(iv) \\
\hline
\end{tabular}

This cultural landscape in the Piedmont and Lombardy regions of northern Italy consists of nine separate areas: 


\begin{tabular}{|l|l|c|r|}
\hline Name & $\begin{array}{l}\text { Province } \\
\text { (Region) }\end{array}$ & $\begin{array}{l}\text { Area } \\
\text { (ha) }\end{array}$ & $\begin{array}{l}\text { Buffer } \\
\text { Zone }\end{array}$ \\
\hline $\begin{array}{l}\text { Mont-Sacré ou "Nuova } \\
\text { Gerusalemme" de Varallo } \\
\text { Sesia }\end{array}$ & $\begin{array}{l}\text { Vercelli } \\
\text { (Piedmont) }\end{array}$ & 5.40 & 26.10 \\
\hline $\begin{array}{l}\text { Mont-Sacré de S.Maria } \\
\text { Assunta de Serralunga di Crea }\end{array}$ & $\begin{array}{l}\text { Alessandria } \\
\text { (Piedmont) }\end{array}$ & 8.90 & 24.10 \\
\hline $\begin{array}{l}\text { Mont-Sacré de San Francesco } \\
\text { d'Orta San Giulio }\end{array}$ & $\begin{array}{l}\text { Novara } \\
\text { (Piedmont) }\end{array}$ & 14.00 & 7.50 \\
\hline $\begin{array}{l}\text { Mont-Sacré du Rosario de } \\
\text { Varese }\end{array}$ & $\begin{array}{l}\text { Varese } \\
\text { (Lombardie) }\end{array}$ & 14.60 & 32.60 \\
\hline $\begin{array}{l}\text { Mont-Sacré de la Beata } \\
\text { Vergine, Oropa }\end{array}$ & $\begin{array}{l}\text { Biella } \\
\text { (Piedmont) }\end{array}$ & 15.40 & 49.60 \\
\hline $\begin{array}{l}\text { Mont-Sacré de la Beata } \\
\text { Vergine del Soccorso, } \\
\text { Ossuccio }\end{array}$ & $\begin{array}{l}\text { Como } \\
\text { (Lombardie) }\end{array}$ & 3.00 & 9.00 \\
\hline $\begin{array}{l}\text { Mont-Sacré de la SS.Trinità, } \\
\text { Ghiffa }\end{array}$ & $\begin{array}{l}\text { Verbania } \\
\text { (Piedmont) }\end{array}$ & 11.00 & 210.00 \\
\hline $\begin{array}{l}\text { Mont-Sacré Calvario, } \\
\text { Domodossola }\end{array}$ & $\begin{array}{l}\text { Verbania } \\
\text { (Piedmont) }\end{array}$ & 3.60 & 41.40 \\
\hline $\begin{array}{l}\text { Mont-Sacré de Belmonte, } \\
\text { Valperga Canavese }\end{array}$ & $\begin{array}{l}\text { Turin } \\
\text { (Piedmont) }\end{array}$ & 14.60 & 321.60 \\
\hline & \multicolumn{1}{|c|}{ TOTAL } & 90.50 & 721.9 \\
\hline
\end{tabular}

\section{Reactivation of a deferred nomination at the request of the Committee}

\begin{tabular}{|l|l|}
\hline Property & Minaret of Jam \\
\hline Id. $\mathrm{N}^{\circ}$ & $\mathbf{2 1 1}$ Rev \\
\hline State Party & Afghanistan \\
\hline $\begin{array}{l}\text { Criteria } \\
\text { proposed }\end{array}$ & \\
\hline
\end{tabular}

The Bureau examined the information concerning the reactivation of the deferred nomination of the Minaret of Jam in Afghanistan contained in document WHC02/CONF.201/12.

The Bureau recalled that:

(a) The original nomination for the Minaret of Jam submitted by the Democratic Republic of Afghanistan was received by the UNESCO Secretariat on 14 April 1982. Jam is located at the border of Ghor and Herat Province and is believed to have been the site of the $12^{\text {th }}$ century Firuzkuh capital of the Ghurid empire (1000 - 1215 CE) which ruled Afghanistan and parts of India in the $12^{\text {th }}-13^{\text {th }}$ centuries. The Minaret of Jam, or the "victory tower" is 65 meters tall and is the second highest minaret in the world that directly inspired the Qutb Minar World Heritage property in New Delhi, India. Made of four tapering cylindrical shafts on an octagonal base and a double spiral staircase inside, the minaret was completely decorated with richly decorated brickwork and blue tile inscription at the top. There is an inscription dating the construction of the Minaret to 1194. The property is composed of several heritage assets, which include the Minaret, a Jewish cemetery, ruins of three watchtowers, a bridge, fortification walls, a castle, a water reservoir, a bazaar, all located within an area of approximately $5 \mathrm{~km}^{2}$.

The State Party agreed to the proposal of ICOMOS that the name of the property in English be: "The Sacri Monti of Piedmont and Lombardy." The Bureau noted that other sites of this type are located in Switzerland (Ticino).

In the general discussion, one delegate asked that the Centre provide a mechanism to follow up on the special recommendations of the Bureau or Committee. The Centre responded that these recommendations are always transmitted to the States Parties with the letter containing the decision of the Bureau or Committee, but agreed that a long-term mechanism should be established between the Committee and the State Parties concerned through the Centre to ensure appropriate follow up.

(b) In 1983, ICOMOS was favourable to the inscription of the Minaret of Jam on the World Heritage List on the basis of cultural criterion (iii). However, at the time, ICOMOS deemed it difficult to accept the nomination due to insufficient information concerning:

- the state of preservation of the monument, which was judged to be alarming in 1974 when two UNESCO experts undertook a technical mission to examine means of consolidating the Minaret;

- the perimeter of the proposed heritage area, which should be sufficiently large to conserve the quality of the beautiful natural surroundings, as well as the archaeological potential of the site.

(c) Upon examination of the evaluation by ICOMOS at its seventh session in June 1983, the Bureau of the World Heritage Committee requested the authorities to redefine the limits of the zone of protection and to 
provide precise information on the present state of conservation of the monument.

(d) At its seventh session in December 1983, the World Heritage Committee decided to defer consideration of the inscription of the Minaret of Jam on the World Heritage List in light of the fact that the State Party had not provided the information requested by the Bureau.

The Director of the World Heritage Centre presented the following information to the Bureau demonstrating the actions taken since the Committee discussed the reactivation of the World Heritage Convention in Afghanistan and the deferred Afghan nominations at its $25^{\text {th }}$ session (Helsinki, December 2001):

(i) In January 2002, the World Heritage Centre identified the Minaret of Jam as the most appropriate deferred nomination to reactivate. This was based on careful consideration of the information available concerning the state of conservation of the four deferred nominations, degree of authenticity and integrity of the property, as well as the location, ownership, size, management capacity and threats facing each property. The Minaret of Jam was deemed to be the most appropriate property among the four deferred nominations in view of the fact that it is a single monument surrounded by a small number of related historical and archaeological heritage assets, which comparatively speaking, are all in fairly good condition. The area that could be defined as the zone of protection could be limited to approximately $5 \mathrm{~km}^{2}$ including the buffer zone.

(ii) On 30 January 2002, the Minister of Foreign Affairs of the Interim Administration of Afghanistan officially requested UNESCO to play a co-ordinating role with archaeologists and international organizations to safeguard Afghanistan's cultural heritage. Moreover, the Interim Administration expressed its wish that UNESCO officially informs all Member States as well as institutions active in the field of heritage protection on this official request and its acceptance by UNESCO.

(iii) Since February 2002, the World Heritage Centre, together with international experts, had been reformulating a draft nomination dossier of the Minaret of Jam for consideration and official submission by the Government of Afghanistan for inscription on the World Heritage List and the List of World Heritage in Danger by the World Heritage Committee at its 26th session.

(iv) On 28 February 2002, the Deputy Minister of Culture of the Interim Administration of Afghanistan officially requested UNESCO to assist in the safeguarding of the Minaret of Jam. (v) In mid-March 2002, complementary action was taken by the Division of Cultural Heritage, UNESCO Sector for Culture, through the organization of an international expert mission to the Minaret of Jam to assess its present state of conservation, to identify emergency conservation requirements and to prepare conservation and restoration proposals. These proposals were being prepared to assist the Afghan authorities' activities to be financed from the US\$ 10 million pledged by the international community during the Tokyo Donors' Conference for the Rehabilitation of Afghanistan in January 2002.

(vi) The international expert mission undertaken by Professor Andrea Bruno to the site on 21 March 2002 found that the Minaret of Jam was in a relatively fair state of conservation. However, he noted the following three major threats to the property:

- clandestine excavation of the archaeological remains of Jam and pillage of carved brick decorating the surface of the Minaret;

- road construction in the immediate vicinity of the Minaret and the archaeological remains being undertaken by an NGO for economic development purposes;

- structural instability of the Minaret, as its foundation requires proper scientific structural examination and consolidation measures to prevent further leaning.

(vii) On 27 March 2002, the Minister of Information and Culture informed the Director of the World Heritage Centre that his Administration welcomes the UNESCO WHC - ICOMOS - IUCN Joint Mission and the Committee's wish to reactivate the World Heritage Convention in his country to protect, conserve and present the heritage of humanity located in Afghanistan.

(viii) The UNESCO WHC - Advisory Bodies Joint Fact-Finding and Consultative Mission would take place between 28 April and 12 May 2002 if security conditions permit. The mission would be composed of the Director of the World Heritage Centre, a Programme Specialist for the AsiaPacific Region of the Centre, and expert representatives of ICOMOS and IUCN.

(ix) The draft reformulated nomination dossier of the deferred property of the Minaret and Archaeological Remains of Jam would be finalised by the Government of Afghanistan for official submission after the Joint Mission, for possible inscription of the property on the World Heritage List and the List of World Heritage in Danger by the Committee at its 26th session.

The Bureau expressed its appreciation to the DirectorGeneral of UNESCO and the World Heritage Centre for its 
initiatives and actions taken to assist the Afghan authorities and the Committee in reactivating the World Heritage Convention in Afghanistan. The Bureau also thanked the Interim Administration of Afghanistan for agreeing to receive the UNESCO WHC - ICOMOS IUCN Joint Mission to Afghanistan scheduled for 28 April - 12 May 2002.

The Representative of Thailand, the Observer of the United Kingdom, and the Representative of ICOMOS underlined the necessity to ensure that the evaluation of the reformulated nomination should be undertaken before the inscription of the property on the World Heritage List and the List of World Heritage in Danger. However, the Delegate of Hungary, the Observer of India and the Director of the World Heritage Centre, recalling the lessons to be learnt from the regrettable destruction of the Bamiyan Buddhas, drew the attention of the Bureau to the important message the Committee could transmit to the international community by recognizing the World Heritage value of the Minaret of Jam, the Afghan cultural heritage property. It was recalled that in accordance with Article 14 of the Convention, it is the Director General of UNESCO who shall prepare the working documents for the Committee.

The Bureau noted the importance of demonstrating the Committee's commitment to assist the Afghan authorities in implementing the World Heritage Convention in Afghanistan, which could include the urgent examination of a reformulated nomination of a deferred property whose World Heritage value was already recognized in 1983. Such action would signify the strengthening of the World Heritage Convention.

Finally, the Bureau recommended that the Committee examine at its 26th session the findings and recommendations of the Joint Mission to Afghanistan, and consider the inscription of the Minaret of Jam as a deferred nomination officially submitted by the Afghan authorities in 1982, and resubmitted in 2002, on the World Heritage List and the List of World Heritage in Danger.

\section{Other heritage properties in Afghanistan:}

At the request of the Delegate of Greece, the Bureau was informed by the representative of the Division of Cultural Heritage that a mission was undertaken by a UNESCO expert to Bamiyan between December 2001 and January 2002. This expert found that:

- The large Buddha is entirely destroyed, and its drainage canals restored in 1998 are in good condition but contain rubble. The walls supporting the arch where the large Buddha was located remains intact, but explosions have produced fractures and frescoes have disappeared.

- The small Buddha is also almost entirely destroyed.

- Some frescoes in caves situated west of the statues have survived but are endangered as signs of looting are evident.The Buddha situated in the Kakrak Valley is also destroyed.

The Bureau was also informed that the Division of Cultural Heritage had organized an international expert mission in March 2002 to the Historic Centre of Herat, another property deferred by the Committee at its seventh session.

\section{Co-ordination of UNESCO actions for heritage protection :}

In response to clarifications requested by the Delegate of Mexico, the Bureau was informed that the World Heritage Centre was not a member of the UNESCO Task Force for Afghanistan. The Director of the World Heritage Centre informed the Bureau that information concerning heritagerelated activities in Afghanistan was received from the Cultural Heritage Division. Furthermore, he pointed out that to date there has been no indication from the Task Force as to the activities related to the World Heritage Convention.

Noting various missions and activities being planned and implemented bilaterally and multilaterally, ICOMOS underscored the importance of UNESCO playing a coordinating role for all heritage activities in Afghanistan, as officially requested by the Interim Administration of Afghanistan. In view of the critical situation in the country and the lack of financial and human resources against the enormous needs, he stated that duplication of efforts should be avoided.

The Bureau invited the Director-General of UNESCO to provide a full report on all actions and initiatives taken by the various divisions of the Sectors for Culture and Science and the World Heritage Centre in assisting the authorities for the protection of the Afghan heritage, for consideration by the Committee at its 26 th session. 
XIV.1 The Bureau approved the following requests for international assistance:

\section{Preparatory Assistance}

Cultural Asia Pakistan

Preparatory assistance for the nomination of the archaeological remains at Ranigat as an extension of Taxila World Heritage site

The Bureau approved US\$ 30,000, subject to the State Party paying its dues to the World Heritage Fund.

\section{Technical Co-operation}

Natural Africa

\section{Senegal}

Derby Eland Monitoring Programme

The Bureau approved US\$ 29,296 for this request, subject to the State Party paying its dues to the World Heritage Fund.

\section{Preparatory Assistance}

Natural Arab States Egypt

Meeting to prepare Tentative Lists for Natural Heritage in the Arab Region.

The Bureau approved this request for US\$ 29,500. The State Party confirmed that it would take into account the questions raised by the Advisory Bodies.

\section{Training}

Cultural Europe Norway

International Course on Wood Conservation Technology

The Bureau approved this request for US \$ 30,000, requesting the State Party to take into consideration the comments of ICCROM.

\section{Training}

\section{Mixed Latin America Argentina}

Sub-regional training workshop on Management and Administration of World Heritage properties.

The Bureau approved this request for US\$ 22,350 requesting the World Heritage Centre to co-ordinate the implementation of the activity in close collaboration with the State Party as well as with the Advisory Bodies to ensure that the meeting is carried out with sub-regional participation.

\section{Training \\ Cultural}

\section{Latin America \& Caribbean Dominican Republic}

Annual Seminary Workshop on Cultural Heritage Risk Prevention for the Caribbean and Central America

The Bureau approved this request for US\$ 30,000, pending clarification by the State Party concerning the questions raised by ICCROM.

\begin{tabular}{lll}
\hline Emergency & Asia & Nepal \\
Cultural
\end{tabular}

Emergency Technical-Co-operation for safeguarding measures at Lumbini, Birthplace of the Lord Buddha World Heritage site

The Bureau recommended reformulation of the request for re-examination by the Committee at its 26 th session.

\section{Emergency \\ Cultural}

\section{Latin America \& Caribbean Brazil}

Emergency Assistance for the Historic Centre of the City of Goiás (Rain and Overflows) :

The Bureau approved US\$ 7,288 as additional emergency assistance for this request.

\section{Emergency}

Cultural

\section{Latin America \& Caribbean Cuba}

Emergency Assistance for the Convent of Santa Clara of Asissi, Old Havana and its Fortifications.

The Bureau approved US\$ 75,000 for this activity.

\section{Technical Co-operation

Cultural Arab States Algeria

Elaboration of a Preliminary Plan of Conservation and Development of the M' Zab Valley.

The Bureau recommended approval of US\$ $\mathbf{3 5 , 0 0 0}$ by the Committee, requesting the World Heritage Centre to coordinate the implementation of the activity in close collaboration with the national authorities concerned.

\section{Training}

Cultural

Asia

Turkmenistan

Reinforcement of the capacities of the Department for Protection and Restoration of Monuments, Turkmenistan, to conserve the World Heritage site of Ancient Merv. 
The Bureau approved an initial US\$ 30,000 for commencing the activity, and recommended that the remaining US\$ $\mathbf{3 8 , 8 1 4}$ be approved by the World Heritage Committee in June 2002.

ICCROM recommended that staff costs should be reduced, and that when international assistance requests fall within the framework of programme initiatives approved by the Committee, this should be clearly indicated in the requests at the time of submission.

\section{Training}

Cultural

Asia

Uzbekistan

Restoration of the medersa "Rachid" at Bukhara World Heritage site

ICOMOS supported the request. ICCROM requested further clarification concerning the capacity-building component of the request. The Bureau recommended reformulation by the State Party and re-examination of the request by the Committee at its 26th session.

XIV.2 The Observer of Canada drew the attention of the Bureau to the existing Operational Guidelines whereby the States Parties' dues must be paid prior to the approval of Preparatory Assistance and Technical Cooperation requests.

\section{PROVISIONAL AGENDA AND TIMETABLE OF THE TWENTY-SIXTH SESSION OF THE WORLD HERITAGE COMMITTEE (BUDAPEST, HUNGARY, 24- 29 JUNE 2002)}

XV.1 The Director of the World Heritage Centre presented document WHC-02/CONF.201/14. He recommended the addition of two items on the agenda:

- $\quad$ "Election of the Chairperson, Rapporteur and Vice Chairpersons"; and

- "Examination of nominations in 2003 and 2004" to follow the discussion on the "Progress report on the analyses of the World Heritage List and tentative lists and the identification of under-represented categories of cultural and natural heritage".

XV.2 He also noted that the Provisional Agenda for the 26th session of the Committee now included 27 items (including an item on the Draft Decision on the protection of the cultural heritage in the Palestinian Territories). $\mathrm{He}$ questioned whether it was feasible to discuss all these items.

XV.3 The Chairperson recalled that earlier in the session, the Bureau had recommended that an extraordinary session be convened sometime after the 26th session of the Committee to discuss strategic issues (see paragraph IX.23 of this report). The Observer of the United Kingdom questioned whether it was practical to organise an extraordinary session of the Committee in 2002 or 2003 and whether the necessary funds were available.

XV.4 The Bureau recommended that the Committee delete of item 5 "Report of the Secretariat on the activities conducted since the 25th session of the Committee" (to be provided as an information document) and item 10 "World Heritage Visual Identity and Legal Protection of the Emblem".

XV.5 The Bureau requested that the Centre re-order the items of the agenda and restructure the timetable to ensure a logical flow and grouping of related agenda items and an appropriate allocation of time for each item. Some items would need to be introduced at the beginning of the Committee session, a working group established and then the item brought back to the Committee for final decision later in the week.

XV.6 The revised Provisional Agenda and Timetable for the 26th session of the World Heritage Committee (Budapest, 24-29 June 2002) is attached as Annex II to this report.

\section{OTHER BUSINESS}

XVI.1 A working group was appointed by the Bureau at its 26th session to prepare a Draft Decision on the prevailing situation in the Palestinian Territories to be submitted to the Committee for adoption at its 26th session in Budapest, June 2002. The working group was composed of the following States Parties: South Africa (Chair); Egypt; Greece; and Hungary. The Secretariat acted as Rapporteur.

XVI.2 The Chairperson recalled that this Draft Decision would be a working document that will be submitted to the Committee in Budapest to serve as a basis for discussion and decision.

XVI.3 Having examined the text prepared by the Working Group, the Bureau recommended by consensus that it be transmitted to the World Heritage Committee for consideration and adoption at its 26th session in Budapest (June 2002).

\section{"The Committee:}

Recalling the Resolution adopted by the 13th General Assembly of States Parties to the World Heritage Convention concerning the means of ensuring better protection of the common heritage of humanity and the relevant decision taken by the Committee at its 25 th session in Helsinki (paragraph IV.16 of the report of the session),

Recalling further the Resolution adopted by the $31^{\text {st }}$ session of the General Conference of UNESCO 
concerning "Acts constituting a crime against the common heritage of humanity" and all the United Nations Resolutions related to the conflict and in particular Resolutions 1397, 1402 and 1403 of the Security Council of the United Nations and the Resolution 53/27 of the General Assembly on Bethlehem-2000,

Noting the provisions of the Convention for the Protection of Cultural Property in the Event of Armed Conflict (The Hague, 1954) and its Protocols, the Convention on the Means of Prohibiting and Preventing the Illicit Import, Export and Transfer of Ownership of Cultural Property (1970), the UNIDROIT Convention, the World Heritage Convention concerning the Protection of the World Cultural and Natural Heritage (1972), the Geneva Conventions (1949) and its Additional Protocols (1977) and other relevant international legal instruments,

Expressing its grave concern for the continuing loss of all innocent lives and at the destruction and damage caused to the cultural heritage in the Palestinian Territories, in particular the reported damage caused to the Basilica of the Nativity in Bethlehem, birth place of Jesus Christ and one of the most significant and historic sites on earth; the historic centre of Nablus including its Mosques and the old City of Hebron,

Emphasizing that, despite the fact that the abovementioned properties are not inscribed on the World Heritage List, this does not mean that they are not of outstanding universal value according to Article 12 of the World Heritage Convention,

Condemns the destruction and damage caused to the cultural heritage in the Palestinian Territories as a "crime against the common cultural heritage of humanity" and strongly urges Israel, as a State Party to the Convention for the Protection of Cultural Property in the Event of Armed Conflict (The Hague, 1954) and its first Protocol and to the World Heritage Convention concerning the Protection of the World Cultural and Natural Heritage, to ensure the protection of all heritage in the Palestinian Territories in its multicultural diversity;

Invites the Director-General of UNESCO to organize a technical fact-finding and consultative mission to investigate, assess and evaluate the extent of the destruction and damage of cultural heritage in the Palestinian Territories and to take appropriate actions for the rehabilitation and restoration of the damaged cultural heritage and restitution of cultural properties, and to this end, appeals to the two concerned parties to co-operate with UNESCO in its efforts in the protection of the cultural heritage;

Further invites the Director-General of UNESCO to take all appropriate actions, in accordance with the mandate of the Organization, and within the framework of relevant UNESCO conventions, to prevent further destruction of cultural heritage in the Palestinian Territories."
XVI.4 The Chairperson, using his prerogative as stated in Article 16.1 of the Rules of Procedure, decided not to open the debate on this matter and deferred it to the next Committee session in Budapest.

\section{ADOPTION OF THE REPORT OF THE SESSION}

During adoption of Section XVI of the Report, the Delegate of Egypt read a statement and requested that it be included as an Annex to the Report (see Annex III).

\section{CLOSURE OF THE SESSION}

In closing the 26th session of the Bureau of the World Heritage Committee, the Chairperson thanked the Bureau members, observers, Advisory Bodies, interpreters and translators for their work during the session. He commented that with the exception of a few items the Bureau had had fruitful discussions. 
BUREAU DU COMITE DU PATRIMOINE MONDIAL /
BUREAU OF THE WORLD HERITAGE COMMITTEE

Vingt-sixième session / Twenty-sixth session

Paris, Siège de l'UNESCO, Salle IV / Paris, UNESCO Headquarters, Room IV

8 - 13 avril 2002 / 8 - 13 April 2002

\section{LIST OF PARTICIPANTS / LISTE DES PARTICIPANTS}

\section{ETATS MEMBRES DU BUREAU / BUREAU MEMBERS}

\section{AFRIQUE DU SUD / SOUTH AFRICA}

H.E. Ms Thuthukile E Skweyiya

Ambassador to France and Permanent Representative to UNESCO

South African Embassy

59, Quai d'Orsay

PARIS 75007

FRANCE

Ms Louise Graham

Counsellor and Deputy Permanent Representative to

UNESCO

South African Embassy

59, Quai d'Orsay

PARIS 75007

FRANCE

Mr Makgolo Makgolo

Deputy Director

Dept. of Environmental Affairs \& Tourism

Private Bag x 447

PRETORIA 001

\section{EGYPTE / EGYPT}

S. Exc. Mme Tahani Omar

Ambassador, Permanent Delegate

Permanent Delegation of Egypt to UNESCO

1 , rue de Miollis

F-75732 Paris Cedex 15

FRANCE

Professor Samir I. Ghabbour

Rapporteur, Egyptian National MAB Committee

Emeritus Professor,

Dept. of Natural Resources,

Inst. of African Research \& Studies,

Cairo University,

12613 Giza (Cairo),
Dr Mohamed Abdel Maksoud

General Director of Egyptian Antiquities

Supreme Council of Antiquities

Cairo Abb Asiyia

Dr Mohamed Sameh Amr

Délégué permanent adjoint

Permanent Delegation of Egypt to UNESCO

1 , rue de Miollis

F-75732 Paris Cedex 15

FRANCE

\section{FINLANDE / FINLAND}

H.E. Mr Esko Hamilo

Ambassador, Permanent Delegate

Permanent Delegation of Finland to UNESCO

1 , rue de Miollis

F-75732 Paris Cedex 15

FRANCE

Mr. Henrik Lilius

Chairperson, World Heritage Committee

Director General

National Board of Antiquities

P.O. Box 913

HELSINKI 00100

Ms Margaretha Ehrström

Researcher

The National Board of Antiquities

P.O. Box 169

FIN-00511 Helsinki

Mr Jukka-Pekka Flander

Senior Adviser

Ministry of the Environment

Land Use Department

P.O. Box 380

FIN-00131 Helsinki 
Ms Satu Heikkinen

Special Adviser

Ministry of Education / International Relations

P.O. Box 29

FIN-00023 Government

Mr Ari Mäki

Deputy Permanent Delegate

Permanent Delegation of Finland to UNESCO

1 , rue de Miollis

F-75732 Paris Cedex 15

FRANCE

\section{GRECE / GREECE}

Mrs Hélène METHODIOU

Counsellor on Cultural Affairs

Délégation permanente de la Grèce auprès de l'UNESCO

1 , rue Miollis,

F-75732 PARIS Cedex 15

FRANCE

Dr. Niki Tselenti

Archaeologist

Directorate of Byzantine and Post Byzantine Antiquities

2, Klepsideas Str.

GR 10555 Athens

Ms Theodotia Loulopoulou

Archaeologist

Directorate of Prehistoric and Classical Antiquities

20, Bouboulinas Str.

GR 10682 Athens

\section{HONGRIE / HUNGARY}

Mr. Zoltán Cselovszki

Président

Office national de protection du patrimoine culturel

Táncsics Mihály utca 1.

1014 Budapest

Dr János Tardy

Secrétaire d'Etat adjoint

Président

Office national de protection de la nature

Költö u. 21

BUDAPEST 1121

Dr Tamás Fejérdy

Président de l'ICOMOS Hongrie

Tancsics Mihaly n.1

BUDAPEST 1014

Dr Zoltán Szilassy

Directeur adjoint

Office national de protection de la nature

Költö u. 21

BUDAPEST 1121
Mr. Istvau DOBRI

Délégué permanent adjoint

Délégation Permanente de la Hongrie auprès de

1'UNESCO

1 , rue Miollis

75015 Paris

M. Tamás Pintér

Chef du Secrétariat du Comité national pour le patrimoine mondial

Szinhàz u.5-9

BUDAPEST 1014

M. Arpád HABONY

Conseiller du Président de l'Office national de protection du patrimoine culturel

Táncsics Mihály utca 1.

1014 Budapest

Dr Lia Bassa

Secrétariat du Comité National du patrimoine mondial

Szinhàz u.5-9

BUDAPEST 1014

Mme. Edit Herboly

Secrétariat du Comité National du patrimoine mondial

Szinhàz u.5-9

BUDAPEST 1014

\section{MEXIQUE / MEXICO}

S. Exc. Javier Barros Valero

Ambassador, Permanent Delegate

Permanent Delegation of Mexico to UNESCO

1 , rue de Miollis

F-75732 Paris Cedex 15

Dr Francisco Javier Lopez Morales

Director Patrimonio Mundial

Institute Nacional de Anthropología e Historia (INAH)

Puebla 95

MEXICO D.F 06700

Dra. Adriana Valadès de Moulines

Permanent Delegation of Mexico to UNESCO

1 , rue de Miollis

F-75732 Paris Cedex 15

\section{THAILANDE / THAILAND}

Prof.Dr.Adul WICHIENCHAROEN

Chairman

National Committee for WHC of Thailand

Office of Environmental Policy and Planning (OEPP)

60/1 Soi Phibulwattana 7, Rama 6 Rd., Phayathai

Bangkok 10400 
Mrs. Prasertsuk CHAMORNMARN

Secretary

National Committee for for WHC of Thailand

Office of Environmental Policy and Planning (OEPP)

60/1 Soi Phibulwattana 7, Rama 6 Rd., Phayathai

Bangkok 10400

\section{ORGANISATIONS PARTICIPANT A TITRE CONSULTATIF / ORGANISATIONS ATTENDING IN ADVISORY CAPACITY}

\section{CONSEIL INTERNATIONAL DES MONUMENTS \\ ET DES SITES (ICOMOS) / \\ INTERNATIONAL COUNCIL ON MONUMENTS AND SITES (ICOMOS)}

Prof. Michael Petzet

President

ICOMOS

49-51 Rue de la Fédération

PARIS 75015

FRANCE

M. Jean-Louis Luxen

Secrétaire général

ICOMOS

49-51 Rue de la Fédération

PARIS 75015

FRANCE

Prof. Henry Cleere

Coordinator

ICOMOS

49-51 Rue de la Fédération

PARIS 75015

FRANCE

Ms Regina Durighello

Assistant Coordinator

ICOMOS

49-51 Rue de la Fédération

PARIS 75015

FRANCE

Mme. Gwenaëlle Bourdin

ICOMOS

49-51 Rue de la Fédération

PARIS 75015

FRANCE

Dr Jukka Jokilehto

ICOMOS

Via Anicia 6

ROME 00153

ITALY

Prof. Peter Fowler

ICOMOS

11 Amwell St

London ECIR IUL

United Kingdom

\section{UNION MONDIALE POUR LA NATURE (UICN) / THE WORLD CONSERVATION UNION (IUCN)}

Mr. David Sheppard

Head, Programme on Protected Areas

IUCN - The World Conservation Union

Rue Mauverney, 28

1196 Gland

Switzerland

Mr. Pedro Rosabal

Programme Officer

Programme on Protected Areas

IUCN - The World Conservation Union

Rue Mauverney, 28

1196 Gland

Switzerland

Ms Georgina Peard

World Heritage Assistant

IUCN - The World Conservation Union

Rue Mauverney, 28

1196 Gland

Switzerland

INTERNATIONAL CENTRE FOR THE STUDY OF THE PRESERVATION AND THE RESTORATION OF CULTURAL PROPERTY (ICCROM) / CENTRE INTERNATIONAL D'ETUDES POUR LA CONSERVATION ET LA RESTAURATION DES BIENS CULTURELS (ICCROM)

Mr. Joseph King

Project Manager

ICCROM

Via di S. Michele, 13 -

00153 Rome

ITALY 
III. OBSERVERS/OBSERVATEURS

(i) STATES PARTIES TO THE WORLD HERITAGE CONVENTION/ ETATS PARTIES A LA CONVENTION DU PATRIMOINE MONDIAL

\section{ALGÉRIE / ALGERIA}

Mr. Sid Ahmed BAGHLI

Conseiller

Délégation permanente d'Algérie auprès de l'UNESCO

1 rue Miollis

75015 Paris

FRANCE

\section{ALLEMAGNE /GERMANY}

H.E. Dr. Norbert KLINGER, Ambassaador, Permanent Delegate

Permanent Delegation of Germany to UNESCO

13-15 Ave. Franklin D. Roosevelt

75008 Paris

FRANCE

Dr. Birgitta Ringbeck, Head of Section

Ministry of Urban Development and Culture

Fürstenwall 25

DUSSELDORF 40219

Mr Frank Burbach

Directeur de Division

Ministry of Foreign Affairs

Auwaitiges Amt 609 B

1 Werderscher Markt

BERLIN 11013

M. Michael Lauber, Deuxième secrétaire

Délégation permanente d'Allemagne auprès de l'UNESCO

13/15 Av. Franklin Roosevelt

75008 Paris

FRANCE

Mme Sabrina Leuger

Délégation permanente d'Allemagne auprès de l'UNESCO

13/15 Av. Franklin Roosevelt

75008 Paris

FRANCE

Mme Brigitte Mayerhofer

Rossinistr. 1

D-80803 München

Dr. Christian SCHULER-BEIGANG

Secretary for World Heritage in Rhineland-Palatinate

Schillerstr. 44

D-55116 Mainz

Mr. Roland OLSCHOWI

Representative of the Federal State of Rhineland-

Palatinate

Schillerstr. 44

D-55116 Mainz

\section{ARABIE SAOUDITE / SAUDI ARABIA}

\author{
M. Saïd MUGHARBEL \\ Conseiller \\ Delegation to UNESCO \\ 1 , rue Miollis \\ 75015 Paris
}

\section{ARGENTINE / ARGENTINA}

H.Exc . Abel PARENTINI POSSE

Delegado Permanente ante la UNESCO

1, rue Miollis, 7th Floor

75015 Paris

FRANCE

Ministro María Susana PATARO

Subdirectora de Organismos Internacionales Ministerio de Relaciones Exteriores,

Comercio Internacional y Culto

Esmeralda 1212, Piso 11

(C1007ABP) Buenos Aires

Ministro María Ruth DE GOYCOECHEA

Delegada Permanente Adjunta ante la UNESCO

1 , rue Miollis

75015 Paris

FRANCE

Secretario Ariel W. Gonzalez

Delegación Permanente ante la UNESCO

1, rue Miollis, 7th Floor

75015 Paris

FRANCE

\section{AUSTRALIE / AUSTRALIA}

\section{Mr Kevin KEEFFE}

Assistant Secretary

World Heritage Branch

Department of the Environment and Heritage GPO Box 787

Canberra ACT 2601

\section{AUTRICHE / AUSTRIA}

Dr. Hans HORCICKA

Director Deputy Head of Dpt. IV/3

Protection of Monuments

Ministry of Education, Science and Culture

Schreyvogelgasse 2/304

A-1010 Vienna 


\section{BELGIQUE / BELGIUM}

S.Exe. Yves Haesendonck,

Ambassadeur, Délégué permanent de Belgique auprès de l'UNESCO

4, villa de Saxe

75007 Paris

FRANCE

M. Marc Thunus

Délégation permanente de Belgique auprès de l'UNESCO

Délégué permanent adjoint

4, villa de Saxe

75007 Paris

FRANCE

Mme Gislaine Devillers

Direction de la Protection

Division du Patrimoine, DGATLP

Ministère de la Région wallonne

Rue des Brigades d'Irlande 1

B-5100 Jambes

Mme Bénédicte Selfslagh

Relations internationales

Division du Patrimoine, DGATLP

Ministère de la Région wallonne

$\mathrm{p} / \mathrm{a}$ avenue Junot 30

F-75018 Paris

Prof. Erik Franckx

Vrije Universiteit Brussel

Pleinlaan 2

1050 Brussel

\section{BÉNIN / BENIN}

Mme. Edith LISSAN

Conseiller

Délégation permanente du Bénin auprès de l'UNESCO

1 , rue Miollis

75015 Paris

FRANCE

\section{CANADA}

Mme. Gisèle CANTIN

Affaires Internationales

Parcs Canada

25 Eddy, 25-6-Y

HULL K1A OM5

Mme. Dominique LEVASSEUR

Chargée des affaires politiques/Political officer

Délégation du Canada auprès de l'UNESCO

1 , rue Miollis

75015 Paris

FRANCE

\section{CHILI / CHILE}

H.E. Mr. Samuel FERNANDEZ-ILLANES

Ambassadeur

Délégation permanente du Chili auprès de l'UNESCO

1 , rue Miollis

75015 Paris

FRANCE

Mr. Alesandro ROGERS

Delegado Permanente Adjunto

Délégation permanente du Chili auprès de l'UNESCO

1 , rue Miollis

75015 Paris

FRANCE

\section{CHINE / CHINA}

Wei-wei SHENG

Deputy Director

Office of International Affairs

State Administration of Cultural Heritage of China

10, North Chaoyangmen Street

Beijing 100020

Mr. Yang Zhijun

Director-General

Department of Cultural Heritage Protection

State Administration of Cultural Heritage

10, North Chaoyangmen Street

Beijing 100020

Mr. Guo Zhan

Assistant Director-General

Department of Cultural Heritage Protection

State Administration of Cultural Heritage

10, North Chaoyangmen Street

Beijing 100020

Mr. Quishan ZOU

Premier sécretaire

Délégation permanente de la Chine auprèes de l'UNESCO

1 , rue Miollis

75015 Paris

FRANCE

\section{COLOMBIE / COLOMBIA}

Mr. Juan Claudio MORALES

Deuxième Secrétaire

Délégation permanente de Colombie auprèes de

l'UNESCO

1 , rue Miollis

75015 Paris

FRANCE 


\section{COSTA RICA}

H.E. Iris LEIVA-BILLAUZT

Ambassadeur

Délégation permanente du Costa Rica auprès de

l'UNESCO

1 , rue Miollis

75015 Paris

FRANCE

\section{ESPAGNE / SPAIN}

Sr. Diego FERNANDEZ

Jefe de Servicio Sub Direccion General de Proteccion del

Patrimonio Historico

Ministerio de Educacion, Cultura y Deporte

Plaza des Rey $n^{\circ} 1$

28071 Madrid

Mme. Iria LOSADA BALTAR

Tecnico de la Subdireccion General de Proteccion del

Patrimonio Historico Espanol

Ministerio de Educacion y Cultura

Plaza del Rey ${ }^{\circ} 1$

28071 Madrid

\section{EL SALVADOR}

Mme. Nanette VIAUD DESROCHES

Conseillere Déléguée Adjointe, UNESCO

1 , rue Miollis 4.23

75015 Paris

FRANCE

\section{EMIRATS ARABES UNIS / \\ UNITED ARAB EMIRATES}

Mr Feddoul KAMMAH

Conseiller

Délégation permanente des Emirats Arabes Unis auprès de

l'UNESCO

1 , rue Miollis

75015 Paris

FRANCE

\section{ETATS-UNIS D'AMERIQUE / UNITED STATES OF AMERICA}

Mr James H. CHARLETON

International Cooperation Specialist

Office of International Affairs

National Park Service

Department of the Interior

P.O. Box 37127

Washington DC 20013-7127
Ms Shirley M. Hart

US Observer to UNESCO

Ambassade des Etats-Unis

2 avenue Gabriel

75382 Paris Cedex 08

FRANCE

Nilse A. Ryman

Political Assistant

Office of the United States Observer to UNESCO

Ambassade des Etats-Unis

2 avenue Gabriel

75382 Paris Cedex 08

FRANCE

\section{FEDERATION DE RUSSIE / \\ RUSSIAN FEDERATION}

\section{Mr Igor MAKOVETSKI}

Chairperson

Russian National Committee for World Heritage Novodevichy proezd, 1 119435 Moscow

\section{FRANCE}

\section{Mme Eva CAILLART}

Ministère de la Culture et de la Communication Membre de la Délégation française pour le Comité du patrimoine mondial

Direction de l'Architecture et du Patrimoine

8 rue Vivienne

75002 Paris

Mme. Catherine DUMESNIL

Conseillère technique pour la culture

Commission nationale française pour l'UNESCO

57, Boulevard des Invalides

75700 Paris 07 SP

\section{GABON}

M. Jean-Marie BOUYOU

Secrétaire général

Commission nationale gabonaise pour l'UNESCO

BP 264

Libreville

\section{GUATEMALA}

Mr. Pablo ARNELAS

Primer Sectario y Consul

Embajada de Guatemala

73 , rue de Courcelles

75008 Paris

FRANCE 


\section{INDE / INDIA}

H.E. Ms Neelah Sabharwal

Ambassador

Delegation of India

1, Miollis

75015 Paris

FRANCE

\section{IRAN (REPUBLIQUE ISLAMIQUE D') / IRAN (ISLAMIC REPUBLIC OF)}

H.E. Ahmad Jalali

Ambassador and Permanent Delegate

Permanent Delegation of Iran to UNESCO

1 , rue Miolis

75015 Paris

FRANCE

Dr. Mohammad Ali ORAIZI

Researcher

36, rue Emeriau

75015 Paris

FRANCE

Dr. Chahryan Adle

Iranian Cultural Heritage Organization (ICHO)

19 rue Cépré

75015 Paris

FRANCE

Mr Javad Safaei

Counsellor

Permanent Delegation of Iran to UNESCO

1 , rue Miollis

Paris 75015

FRANCE

\section{ISRAEL}

\section{S.E. Mr. Yitzhak ELDAN}

Ambassateur

Délégation Permanente d d'Israël auprès de l'UNESCO

Ambassade d'Israël

3 , rue Rabelais

75008 PARIS

FRANCE

Mr. Michael Turner

Chair, Israel World Heritage Committee

Department of Architecture

Bezalel, Academy of Arts and Design

1 Bezalel Street

Jerusalem

\section{ITALIE / ITALY}

S.Exe. M Francesco CARUSO

Ambassadeur

Délégation Permanente d'Italie auprès de l'UNESCO

1 , rue Miollis

75015 Paris

FRANCE

Mme. Alessandra MOLINA

Premier Secrétaire

Délégation Permanente d'Italie auprès de l'UNESCO

1 , rue Miollis

75015 Paris

FRANCE

\section{Luciano MARCHETTI}

Ministère des Biens culturels (Bureau of Umbria)

Via Ulisse Rocchi

Perugia 06100

Mme Giovanna ROSSI

Ministero dell'Ambiente e della Tutela del Territorio

Via C.Colombo 44

Roma 00147

Mr. Pasquale Bruno MALARA

Ministry of Culture (Bureau of Turin)

Piazza San Giovanni 2

10122 Torino

\section{Mme. Lisa ZAFFI}

Ministry of Foreign Affairs DGPC

Ple. Farnesina 1

00194 Roma 1

Mme Marina Misitano

Délégation permanente de l'Italie auprès de l'UNESCO 1 , rue Miolis

75015 Paris

FRANCE

\section{JAPON / JAPAN}

H.E. Mr. Fumiaki TAKAHASHI

Ambassador

Japanese Delegation to UNESCO

1 , rue Miollis

75015 Paris

FRANCE

\section{Mr. Toru YOSHIKAWA}

Third Secretary

Officer in charge of Cultural Affairs

Japanese Delegation to UNESCO

1 , rue Miollis

75015 Paris

FRANCE 
Mr. Hiroshi HORIUCHI

Senior Planning Officer

Biodiversity Policy Division Nature Conservation Bureau

Ministry of Environment, Japan

1-2-2 Kasumigaseki, Chiyoda-ku

Tokyo 100-8975

Dr. Nobuo KAMEI

Director, Architecture and Other Structures Division

Agency for Cultural Affairs (Bunkacho)

3-2-2 Kasumigaseki, Chiyoda-ku

Tokyo 100-8959

Ms. Rimi NAKANO

Deputy Director, Monements and Sites Division

Agency for Cultural Affairs (Bunkacho)

3-2-2 Kasumigaseki, Chiyoda-ku

Tokyo 100-8959

Mr. Tsuyoshi HIRASAWA

Associate Specialist for Cultural Properties

Agency for Cultural Affairs (Bunkacho)

3-2-2 Kasumigaseki, Chiyoda-ku

Tokyo 100-8959

Mr. Kazuhiko NISHI

Associate Specialist for Cultural Properties

Agency for Cultural Affairs (Bunkacho)

3-2-2 Kasumigaseki, Chiyoda-ku

Tokyo 100-8959

Mme. Kumiko YONEDA

Senior Research Scientist

Japan Wildlife Research Center

3-10-10 Shitaya, Taito-ku

Tokyo 110-8676

\section{LITUANIE / LITHUANIA}

Mr. Darius Mereckis

First Secretary

Delegation of Lithuania to UNESCO

1 , rue Miollis

75015 Paris

FRANCE

\section{MALAISIE / MALASIA}

Naharudin AMMILAH

Permanent Delegation of Malaysia

Bureau 7-40 1, rue Miollis

75015 Paris

FRANCE

\section{MALAWI}

Mr. Vivian Chingwalu

Programme Officer

Malawi National Commission for UNESCO

P.O. Box 30278

Lilongwe 3

\section{NÉPAL / NEPAL}

H.E. Indra SINGH

Ambassador

Embassy of Nepal

145 bis, rue des Acacias

75017 Paris

FRANCE

\section{NICARAGUA}

Ms Ximena FLORES

Permanent Delegate

Permanent Delegation of Nicaragua to UNESCO

1 , rue Miollis

75015 Paris

FRANCE

\section{NIGERIA}

Mme. Fatima OTHMAN

Counsellor

Nigerian Delegation to UNESCO

1 , rue Miollis

75015 Paris

FRANCE

\section{OMAN}

H.E. Dr. Musa BIN JAFAR HASSAN

Ambassador

Permanente Delegation of Oman to UNESCO

1 , rue Miollis

75015 Paris

FRANCE

Mr. Kamal Hassan MACKI

Deputy Permanent Delegate

Permanent Delegation of OMAN to UNESCO

1 , rue Miollis

75015 Paris

FRANCE

\section{PAKISTAN}

Mrs. Rukhsana ZIA

Deputy Permanent Delegation of Pakistan to UNESCO

1 , rue Miollis

75015 Paris

FRANCE 


\section{PAYS-BAS / NETHERLANDS}

Ms Sabine Gimbrère

Ministry of Culture

Boite postale 25000

2700 LZ Zoetermeer

Mr Herald Voorneveld

Permanent Delegation of the Netherlands

7, rue Eblé

75007 PARIS

FRANCE

\section{PEROU / PERU}

Mr Carlos Vasquez Corrales

Counsellor

Permanent Delegation of Peru to UNESCO

1 , rue Miollis

PARIS 75015

FRANCE

Mr. Carlos CUETO

Conseiller

Permanent Delegation of Peru to UNESCO

1 , rue Miollis

PARIS 75015

FRANCE

\section{PHILIPPINES}

Mme. Deanna Ongpin-Recto

Foreign Affairs Adviser

Permanent Delegation of the Philippines to UNESCO

1 , rue Miollis

75015 Paris

\section{PORTUGAL}

S. Exc. M. Marcello Mathias

Ambassadeur

Délégué Permanent

Délégation Permanente du Portugal auprès de l'UNESCO

1 rue Miolis

75732 Paris

FRANCE

M. José Augusto França

Rua da Escola Politécnica, 49- $4^{\circ}$ direito

1250-099 Lisboa

M. Eduardo Carqueijeiro

Directeur regional de l'Environnement

Secretaria Regional do Ambiente

Rua Cônsul Dabney, colónia alemã, 140

9900-014 Horta

Açores
Mme Ana Zacarias

Déléguée Permanente Adjointe

Délégation Permanente du Portugal auprès de l'UNESCO

1 rue Miolis

75732 Paris

\section{REPUBLIQUE DE COREE / REPUBLIC OF KOREA}

Mr. Daesoo KANG

Second Secretary

Délégation de République de Corée

1 , rue Miollis

75732 PARIS Cedex 15

FRANCE

\section{REPUBLIQUE TCHÈQUE / CZECH REPUBLIC}

Mr. Karel KOMAREK

Permanente Delegate to UNESCO

1 , rue Miollis

75015 Paris

FRANCE

Mr. Zdenek NOVAK

Vice Minister

Ministry of Culture

Milady Horákové 139

16041 Prague

Mr. Michal BENEŠ

Secrétaire pour les Affaires culturelles de l'UNESCO

Ministère de la Culture

Milady Horákové 139

16000 Praha 6

\section{RÉPUBLIQUE-UNIE DE TANZANIE / UNITED REPUBLIC OF TANZANIA}

Mr. Mohammed SHEYA

Deputy Permanent Delegate of United Republic of Tanzania to UNESCO

1, ave. Raymond Poincaré

750116 Paris

FRANCE

\section{ROYAUME-UNI / UNITED KINGDOM}

Ms. Sheelagh Evans

Head of Historic Environment Protection Branch

Architecture and Historic Environment Division

Department for Culture, Media and Sport

2-4 Cockspur Street

London SW1Y 5DH 
Dr Christopher Young

Head, World Heritage and International Policy

English Heritage

23 Savile Row

London W1S 2ET

Dr Tony Weighell

JNCC

Monkstone House

City Road

Peterborough PE1 1JY

Mr Paul McCormack

Historic Environment Protection Branch

Architecture and Historic Environment Division

Department for Culture, Media and Sport

2-4 Cockspur Street

London SW1Y 5DH

\section{SAINTE-LUCIE / SAINT LUCIA}

Mme. Vera LACOEUILHE

Deputy Permanent Delegate

Permanent Delegation of Saint Lucia to UNESCO

1 , rue Miollis

75015 Paris

FRANCE

\section{SAINT-SIEGE / HOLY SEE}

Mr. Lorenzo Frana

Observateur permanent du Saint-Siège auprès de l'UNESCO

Maison de l'UNESCO

1 , rue Miollis

75732 PARIS Cedex 15

Mr Gilles Delianne

Directeur

Centre Catholique International pour l'UNESCO

9, rue Cler

75007 Paris

FRANCE

\section{SLOVAQUIE / SLOVAKIA}

S.Exe. Mária Krasnohorská

Ambassadeur et Délégué permanent

Délégation permanente de la République slovaque auprès de l'UNESCO

1 rue Milois

75352 Paris CEDEX

FRANCE

Ms Magdaléna Pohlodová

Délégué permanente adjoint

Délégation permanente de la République slovaque auprès de l'UNESCO

1 rue Milois
75352 Paris CEDEX, FRANCE

Ms Jozef Klinda

General Director

Environmental Conceptions, Law and Informatics

Division

Ministry of the Environment

Nam. L. Stura 1

81235 Bratislava

Ms Katarina Nováková

Director

Ministry of the Environment

Nam. L. Stura 1

81235 Bratislava

Ms Viera Dvořáková

Head of Division, Research, Methodology \& Theories

Monuments Board of Slovak Republic

Cesta $\mathrm{Na} \# 268$

Erveny Most 6

BRATISLAVA 81406

\section{SLOVENIE / SLOVENIA}

Dr. Jelka Pirkovič

Under Secretary of State

Ministry of Culture

Cankarjeva 5

1000 Ljubljana

Ms Marjutka Hafner

Under Secretary of State

Slovenian National Commission for UNESCO

Tivolska 50

1000 Ljubljana

\section{SRI LANKA}

Dr. Tampalawela T. DHAMMARATANA

B.P. 37

94344 Joinville

FRANCE

\section{SUISSE / SWITZERLAND}

S.Exe. M. Denis Feldmeyer

Ambassadeur, Délégué Permanent

Délégation Permanente de la Suisse auprès de l'UNESCO

1 , rue Miollis

PARIS 75015

FRANCE

\section{TUNISIE / TUNISIA}

Mr Wacef CHIHA

Délégué Permanent Adjoint de la Tunésie auprès de l'UNESCO

1 , rue Miollis

75015 Paris

FRANCE 


\section{TURQUIE / TURKEY}

Mr Sebnem INCESU

First Secretary

Permanent Delegation of Turkey to UNESCO

1 , rue Miollis

75732 Paris Cedex 15

FRANCE

\section{UKRAINE}

Mr Alexandre PCEVAKO

Délégation d'Ukraine auprès de l'UNESCO

1 , rue Miollis

75732 Paris Cedex 15

FRANCE

\section{(ii) OTHER OBSERVERS / AUTRES OBSERVATEURS}

Permanent Mission of Palestine to UNESCO / Mission permanente d'Observation de la Palestine auprès de l'UNESCO

H.E. Mr Ahmad Abdelrazek

Ambassador

Permanent Delegate

Delegation of Palestine to UNESCO

1 , rue Miollis

PARIS 75015

FRANCE

Mr Mohammed Yakoub

Conseiller

Delegation of Palestine to UNESCO

1 , rue Miollis

PARIS 75015

FRANCE

\section{VENEZUELA}

Mr Javier Diaz

Premier Secrétaire

Délégation de Venezuela auprès de l'UNESCO

1 , rue Miollis

75732 Paris Cedex 15

FRANCE

\section{ZIMBABWE}

Mr Dawson Munjeri

Deputy Permanent Delegate to UNESCO

Permanent Delegation of Zimbabwe to UNESCO

Embassy of the Republic of Zimbabwe

12, rue Lord Byron

75008 Paris

FRANCE
Mr Issa Wachil

Conseiller

Delegation of Palestine to UNESCO

1 , rue Miollis

PARIS 75015

FRANCE

Mr Abdelrahim Alfarra

Conseiller

Delegation of Palestine to UNESCO

1 , rue Miollis

PARIS 75015

FRANCE

(iii)
INTERNATIONAL GOVERNMENTAL ORGANIZATIONS AND NON-GOVERNMENTAL ORGANIZATIONS / ORGANISATIONS GOUVERNEMENTALES INTERNATIONALES ET ORGANISATIONS NON-GOUVERNEMENTALES

\section{FONDATION DES NATIONS UNIS / UNITED NATIONS FOUNDATION}

Mr Raymond E. Wanner

Senior Adviser on UNESCO Issues

United Nations Foundation

9143 Sligo Creek Parkway

Silver Spring, Maryland 20901

USA

\section{BUREAU NORDIQUE DU PATRIMOINE MONDIAL / NORDIC WORLD HERITAGE OFFICE}

Ms Anne-Kristin Endresen

Director

Nordic World Heritage Office

Dronningens Gate 13

P.O.Box 8196, Dep.

OSLO 0034

NORWAY 
Prof. Synnøve Vinsrygg

Senior International Advisor

Nordic World Heritage Office

P.O.Box 8196 Dep.

N-0034 OSLO

NORWAY
Programme des Nations Unies pour l'Environnement (PNUE) / United Nations Environmental Programme (UNEP)

Mr. Daniel Drocourt

Coordinateur Programme 100 sites historiques PAM/PNUE

Atelier du Patrimoine mondial de la ville de Marseille 10 ter Square Belsunce 13001 Marseille FRANCE

\section{(iv) POSTGRADUATE OBSERVERS}

Mr. Mael LEROYER

Observateur (Etudiant)

Université paris I

126, rue d'Avran

75020 Paris

FRANCE
Ms Cate TURK

Postgraduate Researcher

Department of Geography

University of Edinburgh

Drummont Street

Edimburgh EH8 9XP

Scotland UK

\section{UNESCO SECRETARIAT / SECRETARIAT DE L'UNESCO}

Mr Mounir Bouchenaki

Assistant Director-General for Culture

\section{World Heritage Centre}

Mr Francesco Bandarin

Director

Ms Minja Yang

Deputy Director

Mr Natarajan Ishwaran Ms Elizabeth Wangari Ms Mechtild Rössler Ms Carmen Negrin Ms Sarah Titchen Mr Giovanni Boccardi Ms Junko Taniguchi Ms Frédérique Robert Ms Vesna Vujicic-Lugassy
Mr Jing Feng

Ms Marjaana Kokkonen

Ms Alexandra zu Sayn-Wittgenstein

Ms Isabelle Connolly

Ms Marie Luisa Bascur

Mr Peter Stott

Mr Mario Hernandez

Ms Joanna Serna-Sullivan

Ms Junko Okahashi

Ms Jane Degeorges

Mr Alessandro Balsamo

Ms Margarita Gonzalez-Lombardo

Ms. Réjane Hervé-Smadja

Ms Marianne Raabe
Mr David Martel

Ms Nina Dhumal

Mr John Donaldson

Chief,

General Legal Affairs Section

Translators:

Ms Sabine de Valence

Ms Anne Sauvêtre

Interpreters:

Ms Catherine Lattanzio-Hinthaas

Ms Chantal Bret

Mr Charles Speed

Mr David Shearer

\section{ADVISOR TO THE ASSISTANT DIRECTOR GENERAL FOR CULTURE}

Dr Bernd von Droste 


\section{UNITED NATIONS EDUCATIONAL, SCIENTIFIC AND CULTURAL ORGANIZATION \\ CONVENTION CONCERNING THE PROTECTION OF THE WORLD CULTURAL AND NATURAL HERITAGE}

WORLD HERITAGE COMMITTEE

Twenty-sixth session

Provisional Agenda and Timetable of the twenty-sixth session of the World Heritage Committee (Budapest, Hungary, 24-29 June 2002)

\section{CELEBRATION OF THE 30TH ANNIVERSARY OF THE WORLD HERITAGE CONVENTION}

1. Welcome by the Director-General of UNESCO or his representative

2. Reports on 30 years of the World Heritage Convention

3. The Budapest Declaration on World Heritage

\section{OPENING OF THE SESSION}

4. Adoption of the agenda and the timetable

5. Election of the Chairperson, Rapporteur and Vice-Chairpersons

6. Report of the Rapporteur on the twenty-sixth ordinary session of the Bureau of the World Heritage Committee

7. Report of the Secretariat on the activities undertaken since the twenty-fifth session of the Committee

8. Progress report on the preparation of the 30th Anniversary of the World Heritage Convention

9. Draft decision on the protection of the cultural heritage in the Palestinian Territories

\section{PROGRESS REPORTS ON REFORMS AND STRATEGIC REFLECTION}

10. Overview of progress with reforms and strategic reflection

11. Ways and means to reinforce the implementation of the World Heritage Convention

12. Policy/legal issues concerning inscription of properties on the List of World Heritage in Danger and the potential deletion of properties from the World Heritage List 
13. Progress report on the analyses of the World Heritage List and Tentative Lists and the identification of underrepresented categories of natural and cultural heritage

14. Examination of nominations in 2003 and 2004

15. World Heritage visual identity and legal protection of the Emblem

16. Discussion on the relationship between the World Heritage Committee and UNESCO

17. Progress report on the preparation of the proposed Strategic Orientations of the World Heritage Committee and revised structure of the budget of the World Heritage Fund

18. Revision of the Operational Guidelines

19. Revision of the Rules of Procedures of the World Heritage Committee

\section{IMPLEMENTATION OF THE WORLD HERITAGE CONVENTION}

20. Periodic Reporting: Report on the state of the World Heritage in Africa, 2001

21. State of conservation of properties inscribed on List of World Heritage in Danger and on the World Heritage List

22. Progress made in assisting Afghanistan in the implementation of the World Heritage Convention

23. Information on tentative lists and examination of nominations of cultural and natural properties to the List of World Heritage in Danger and the World Heritage List

24. Adjustments to the World Heritage Fund Budget for 2002-2003

25. International assistance

\section{CLOSING}

26. Provisional agenda and timetable of the twenty-seventh session of the Bureau of the World Heritage Committee (April 2003)

27. Provisional agenda and timetable of the twenty-seventh session of the World Heritage Committee (June 2003)

28. Other business

29. Adoption of the report of the session

30. Closure of the session

The Timetable is under preparation and will be distributed with the dispatch of the working documents for the Committee session. 


\section{Egyptian Statement Concerning}

Agenda item "other business"

\section{presented on 13 of April 2002 (closing session of the Bureau)}

Egypt, as a Member State of the Bureau, wishes to confirm its position that it did not oppose in any manner - oral comments to be presented by any observer attending the Bureau meeting when discussing the item titled "other business" which relates to the situation of cultural heritage in the Palestinian Territories.

The discussion of the Member States of the Bureau, at that time, showed clearly and undoubtedly that they wanted to allow the observers to express oral comments in accordance with the normal practice of the Bureau. This fact was over looked on part of the Chairperson who focused only on the issue of the right of the observers to present written comments regarding this item and decided not to allow any observer to present oral or written comments regarding this item.

We wished that all observers, including the concerned parties, would be given the opportunity to express their views orally in accordance with the standard practice of the Bureau.

We believe that our main objective is to pay great attention to the protection of cultural heritage without involving political considerations.

The position applied by the Bureau and the Committee regarding the protection of cultural heritage in Afghanistan should be followed to any case of damage or destruction caused to the cultural heritage, which has a universal value, any where in the world. 